\title{
An Updated Overview of Herpes Simplex Virus-1 Infection: Insights from Origin to Mitigation Measures
}

\author{
Abu Tayab Moin ${ }^{1}$, Mohammad Al-baruni Chowdhury ${ }^{1}$, Sumaiya Hafiz Riana ${ }^{1}$, Md. Asad Ullah ${ }^{2}$, Yusha Araf ${ }^{3}$, \\ Bishajit Sarkar ${ }^{2}$, Abdullah Mohammad Shohael ${ }^{*}$
}

\begin{abstract}
${ }^{1}$ Department of Genetic Engineering and Biotechnology, Faculty of Biological Sciences, University of Chittagong, Chattogram, BANGLADESH ${ }^{2}$ Department of Biotechnology and Genetic Engineering, Faculty of Biological Sciences, Jahangirnagar University, Dhaka, BANGLADESH

${ }^{3}$ Department of Genetic Engineering and Biotechnology, Faculty of Life Sciences, Shahjalal University of Science and Technology, Sylhet, BANGLADESH *Corresponding Author: amshohael@juniv.edu
\end{abstract}

Citation: Moin AT, Chowdhury MA-b, Riana SH, Ullah Md.A, Araf Y, Sarkar B, Shohael AM. An Updated Overview of Herpes Simplex Virus-1 Infection: Insights from Origin to Mitigation Measures. Electron J Gen Med. 2021;18(4):em299. https://doi.org/10.29333/ejgm/10869

ARTICLE INFO

Received: 26 Sep. 2020

Accepted: 3 Mar. 2021

\begin{abstract}
Purpose: High prevalence of recurrent HSV-1 (Herpes Simplex Virus 1) and its facile mode of transmission requires an elaborated understanding of the virus for mollification. To mitigate its pervasive nature that greatly affects both men and women, a thorough understanding of the viral genome and epidemiology are prerequisites. The review focuses on the existing facts of HSV-1 and acknowledges the prospect of ongoing epidemiological studies.

Findings: Recent data indicates a surge of HSV-1 infection in the age ranged 30-50 years along with the emergence of neonatal cases. The newfound receptors indicate the effect and degree of susceptibility of the host and support the statistical data of HSV-1 seropositivity. Recent studies also show that the evolving virus has gained resistance against widely used antiviral drugs such as Acyclovir (ACV). Therefore, trials of several vaccines (eg. GEN-003and HerpV) are garnering attention as a possible prevention method.

Summary: As most natural viruses are radically evolving, ensuing rather fatal consequences than previous wild types, every virus requires to be tackled with equal importance. Developing vaccines and potent drugs to eradicate viruses from infected subjects' systems can be the only way to prevent future viral epidemics or pandemics. Therefore, early detection of the virus with accurate assay following immediate treatment can only prevent the cases from future catastrophe.
\end{abstract}

Keywords: herpes simplex virus, infection, neonatal HSV-1, pathogenesis, vaccine

\section{INTRODUCTION}

Herpes viruses are double-stranded DNA viruses belonging to the Herpesviridae family [1,2]. It consists of spiky enveloped particles (180 nm in diameter) and has a capsid (100-110 nm in diameter) of icosahedral shape which encompasses a large DNA of genome size around $152 \mathrm{kbp}$. Herpesviruses can be categorized into three subfamilies: alpha, beta, and gamma whereas the alphaherpesvirus subfamily comprises Herpes Simplex Virus-1(HSV-1) in humans [3-5]. The first form of the Herpes virus is responsible for the appearance of characteristic febrile vesicles which normally affect the facial skin, also called herpes simplex labial. Herpes labialis, commonly known as cold sores or fever blisters in the lip, is a common skin condition caused by Herpes Simplex Virus type 1 (HSV-1) $[2,6]$. HSV- 1 is a recurrent virus that causes relapse in approximately one-third of all the infected patients $[7,8]$ with mild morbidity, it can be harmful to it's frequent and/or severe recurrence [9]. There is currently no cure for herpes labialis outbreaks $[6,10]$. The prevalence of herpes labialis is 2.5 per 1000 patients per year and its average incidence is 1.6 per 1000 patients per year [7,11]. Approximately $20-40 \%$ of adults are affected by HSV- 1 at some point in their lives $[6,12]$.
The mode of transmission of HSV-1 is by direct contact with body fluids. Also, if an individual comes in contact with the injuries of an infected person, the virus can be transmitted to that individual. Transmission can also take place even if symptoms are absent in an infected individual. It is predominantly transmitted by oral-to-oral contact that leads to oral herpes infection, employing contact with the HSV-1 virus in saliva, sores, and surfaces surrounding the mouth. Moreover, HSV-1 can be transmitted via sexual contact and genital herpes may also occur due to the transmission of HSV1 by oral-genital contact $[2,6]$. Direct lytic infection or the reactivation of viruses inside latently infected neurons following by the transportation to the infected sites is the major phenomenon before bruise formation. Besides these conventional signs, HSV-1 can induce lesions at other regions, for example, on fingers (known as herpetic whitlow), at abrasion sites(called herpes gladiatorum), and on eyelids (also called herpes blepharitis). In addition to that, HSV-1 can cause inductive infections in the tissues of the cornea that leads to herpes keratitis and conclusively results in corneal scarring and vision impairment or blindness. The HSV-associated disease becomes malignant when the virus gets access to the central nervous system, which may result in herpes encephalitis $[1,13,14]$. This article provides a comprehensive overview of the 


\section{Genomic Organization of Herpes Symplex Type 1 virus}

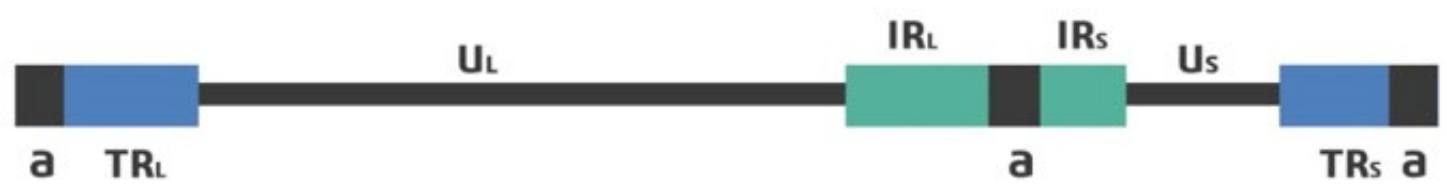

Figure 1. Genomic organization of the HSV-1. The genome is around $152 \mathrm{kbp}$ in legth containing two terminal region in both ends, two internal regions and two unique regions.

origin, hosts, pathogenesis, sign and symptoms, diagnosis methods, and mitigation measures about the HSV-1 infection. The scientific essence of this study contribute to understand the modes of HSV-1 infection, its management, treatment, and preventive measures and to uphold the research efforts on this virus.

\section{EVOLUTIONARY DATA ON HSV-1}

The herpesvirus has evolved alongside the evolution of humans and its primate ancestors, co-diverging from the older ancestors to the newer ones throughout the millions of years of primate speciation. Among all the strains of alphaherpesvirus, HSV-1 has supposedly co-speciated with its primate hosts by creating viral duplications among the different species and transmitting the viral DNA among its descendants $[15,16]$. The analysis based on the molecular clock of primates suggests that the patterned codivergence of the herpesvirus into HSV-1 has occurred through human ancestors such as the largest primate family Cercopithecidae to the superfamily called Ceboidea [17]. As the genera Homo and Pan are proved to have developed through speciation process occurring approximately more than 6 million years ago, one of the mammalian herpesvirus called ChHV found in chimpanzee (Pan troglodytes) and the human simplex virus or HSV are linked through host-virus codivergence due to the close relation between ChHV, HSV-2 and HSV-1 [17,18,19]. The phylogenetic analysis of ChHV via ELISA confirmed its close relation with the alphaherpesvirus subtypes HSV1 and HSV2 as the analysis placed the ChHV in the same clade as the two human simplex virus types [20]. By conducting MUSCLE V2.0 on the ChHV and HSV-1 genomes' 12 conserved regions, the HSV1 is indicated to have codiverged from the ChHV approximately 6 million years ago [17] (Figure 1). Furthermore, an analysis based on molecular dating and phylogenesis was conducted the most conserved region of HSV-1 (US7 and US8 of the HSV1 genome) of the strains having least number of recombinations among their genomes which showed the most recent common ancestors to have developed approximately 710,000 years ago, indicating the viral-host divergence phenomenon of HSV-1 [21]. This phenomenon indicates that the herpes simplex virus has evolved itself from its ancestral strains to infect its hosts which had evolved from the previous older and new world monkeys to become a much more complex homo species.

The prospect of understanding the evolutionary history of mammalian HSV-1 is related to genomic phenomenons such as specification and codivergence, which may give rise to novel recombinant or mutant strains of current HSV-1 strain and possible resistant strain formation as a consequence. The mutation and recombination history taking place in a period of approximately a million years, during which period the current form of a virus evolved to be able to infect humans, can link the specific genomic causes of pathogenesis.

\section{MODE OF TRANSMISSION}

HSV-1 is a pervasive pathogen that is mostly restricted to primates and prolonged infection. HSV-1 is a pervasive pathogen that is mostly restricted to primates and well known for its lifelong infection [2]. Generally, the transmission of HSV1 occurs via the contact of an infected person to an uninfected person [22]. The virus can be transmitted through physical contact if exchange or exposure of -saliva, oro-facial lesion, mucous membrane, genital fluids occurs or if corneal transplantation from an infected to healthy person occurs. Moreover, Viral load is found maximum in fluids of oral labial or genitalia lesions. Thus, the risk of transmitting the virus increases if these fluids are exchanged [23]. Furthermore, the transmission of the virus during childbirth generally happens as the neonate is exposed to HSV-1 in the vaginal tract of an infected mother, where the viral shedding is frequent in case of genital herpes simplex virus infestation. The risk of transmission is significantly greater in women, infected by HSV during pregnancy than women who have longstanding infections [24,25]. Besides, involvement in sexual contact with the person of asymptomatic and symptomatic carriers may lead to high-risk of infection [26].

The list of primates hosts the viruses are given in Table 1. There are in total eight forms of herpes virus. Alpha herpes virus shows a wide range of host diversity, showing latent infection in most of the cases and exhibit less severity to its host [27]. Whereas, Herpes B virus, naturally occurring host is Asian Monkeys of genus MACACA. Which generally, don't infect the monkey but it can create a serious health issue, when it transmitted to other host species [28-30]. The chimpanzee herpes virus (ChHV), which is the first discovered non-human herpes virus found in a chimpanzee is closely related to HSV-2 [31]. Besides baboons, macaques, spider monkey, squirrel monkey, African green monkey, and langur which are the nonhuman primates, seen to be infected with HVP-2, MHV-1, HVA1, HVS-1, CeHV-2 and HVL respectively [32-36].

ChHV is closely related to HSV-2 than HSV-1, which indicates that one of these viruses arose via host-virus codivergence $[31,40]$.

It is clear that HSV-1 and HSV-2 generally infects only humans among the primates whereas other primates are infected with diverse types of herpes simplex virus. Besides, the transmission of HSV-1 in host occurs via direct contact of infected and uninfected person and exchange of viral load containing elements. Moreover, proper precautions should 
Table 1. List of primates prone to HSV-1 pathogen and transmission

\begin{tabular}{cccc}
\hline Virus & Virus Abbreviation & Host Latin Name & Host common name \\
\hline Chimpanzee herpes virus & ChHV & Pan troglodytes & Chimpanzee \\
\hline Baboon herpesvirus 2 & HVP-2 & Papio spp. & Baboons \\
\hline Cercopithecus herpesvirus 2 & CeHV-2 & Chlorocebus pygerythrusa & African green monkey \\
\hline Macacine herpes virus 1 & MHV-1 & Macaca spp. & Macaques \\
\hline Saimiriine herpes virus & HVS-1 & Saimiri sciureus & Squirrel monkey \\
\hline Langur herpesvirus & HVL & Semnopithecus & Langur \\
\hline Herpes simplex virus 1 & HSV-1 & Homo sapiens & Human \\
\hline Herpes simplex virus 2 & HSV-2 & H. sapiens & Human \\
\hline Spider monkey herpes virus & HVA-1 & Ateles geoffroyi & Spider monkey
\end{tabular}

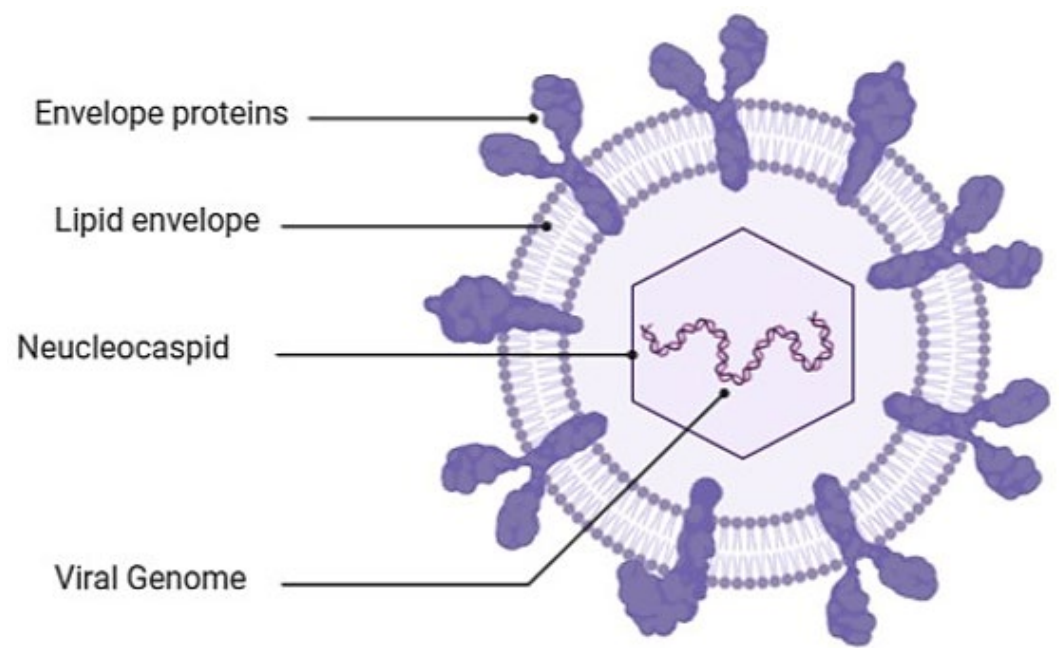

Figure 2. Structure of the HSV-1. HSV-1 includes lipid envelope surrounded by the envelope proteins. It contains viral genome occupied inside the nucleocapsid. The figure was created in BioRender.com and exported under the terms of premium subscription.

maintain during childbirth of an HSV infected mother to have the neonates safe.

\section{PATHOGENESIS OF HSV-1 INFECTION}

HSV1 can carry out lytic (or primary) as well as latent infections [41-43]. The oral mucosa contains epithelial cells where lytic infections usually occur and subsequently lead to cold sores and lesions. The primary infection site is predominantly the oral mucosa whereas genital mucosa can rarely be infected as well. Not only that, but the other epithelial zones at the periphery are also jeopardized by this infection. Patients with no existing antibodies to HSV-1 are the victim of the primary infection. The mucosa or abraded skin must come in direct contact with the virus for the occurrence of the infection. Thus, sexual contact is considered as a route of transmission in young people $[41,44,45]$. If a child comes in contact with primary exposure to HSV-1 and gets infected, it may cause a clinical symptom called acute herpetic gingivostomatitis after 5-10 days of the infection. On the contrary, as the consequence of the primary infections in adults, pharyngitis skin may be produced as well as a mononucleosis-like syndrome that may occur that includes blisters and raw throats. The viral envelope interacts with a host cell membrane through the receptor-mediated fusion. Envelope protein is a structural protein that facilitates the fusion of the virus inside the host cell (Figure 2) The envelope of HSV-1 contains glycoprotein gD that must bind to any of its receptors to ensure the entry inside the cell $[45,46]$.
"Herpesvirus entry mediator" (HVEM) and nectin-1 are the two well-identified receptors for HSV-1 by which the host cell membrane is fused with the viroid envelope. Hence the infectious cycle of HSV-1 is commenced. Adequate numbers of glycoproteins ( $\mathrm{gD}, \mathrm{gB}$, and the heterodimeric complex $\mathrm{gH} / \mathrm{gL}$ ) in the envelope of HSV-1 are required for this intricate process called fusion [46-48]. Fusion is followed by the release of viral capsid into the cytoplasm. Once discharged into the cytoplasm, viral capsids are imported along with the microtubules towards the microtubule-organizing center (MTOC) and hence to the nuclear envelope. After the association of the capsids with nuclear pores, the viral genome becomes uncoated which penetrates the nucleoplasm via the nuclear pore. Later on, the lytic replication takes place and thus primary infection occurs that results in some ordinary symptoms including blisters or oral sores. But, the primary infection may also be asymptomatic that leads the virus to the latency phase [49].

The virus moves towards the sensory ganglion, dorsal root ganglia (DRG) innervating the primary lesion, migrating forward to latent infection, and becomes inactive or dormant [14,50-52]. During latent infection, virus particles get entry to the neuronal axons and move to neuronal nuclei of the cell body in the tri-germinal ganglion, the place where the viral genome, as an extra-chromosomal element, is integrated into a repressed chromatin structure. Although tens to hundreds of viral genomes may take place in the individual latently infected neurons, the viral genes of the lytic cycle remain unexpressed. The majority of the genome undergoes silent transcription apart from the latency-associated transcripts or LATs. 


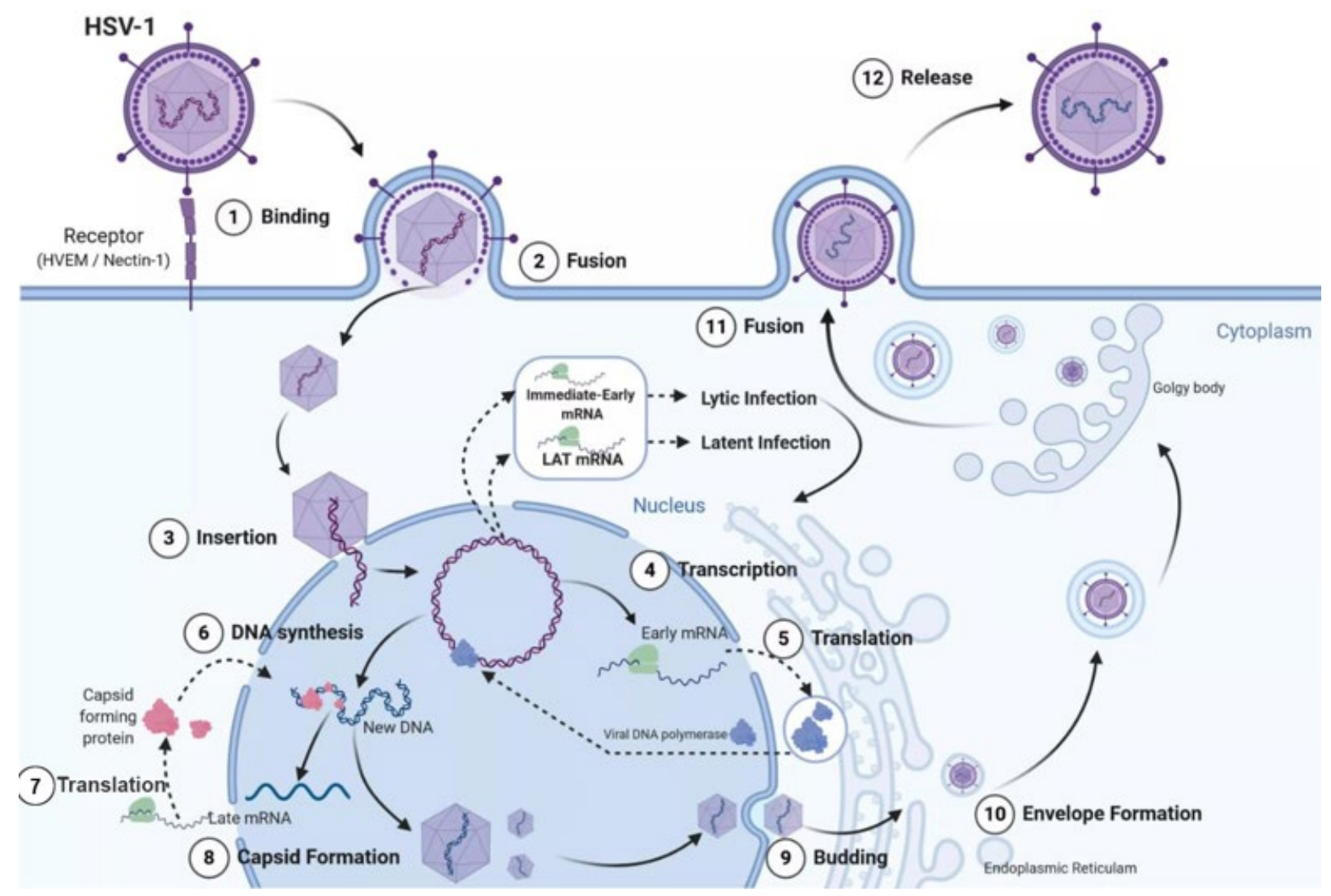

Figure 3. Pathogenesis of the HSV-1. HSV-1 binds with the receptor of the target cell to be fused and enter the cell. After its succesful entry DNA is inserted into the nucleus following by the transcription of Early mRNA. Thereafter, new DNA is synthesized following by the transcription of late mRNA which afterwards wind up the formation of capsid. Finally, budding facilitates to form the envelope and further processings to release the virus out of the cell. The figure was created in BioRender.com and exported under the terms of premium subscription.

Consequently, no or very few replications of viral DNA occurs. During this period, HSV-1 outsmarts the human immune system via several mechanisms. One of them is the induction of an intercellular accumulation of CD1d molecules in antigenpresenting cells. Hence, latently infected neurons are maintained for a long period and as the virus cannot be evacuated, the infected individuals bear the virus for life. Neurons containing the latent HSV-1 genomes are concentrated in the trigeminal ganglion because these predominantly innervate epithelial cells of the oral region.

The virus may reactivate when people undergo certain stresses. This is also called recurrence which is triggered by genotoxic stress, fiver, certain illness, ultraviolet light exposure, fatigue, hormonal imbalance (e.g. during menstruation), immune depression, and mental shock to a site or a nerve region where earlier HSV infection took place $[14,41,49,53]$.

After the stimulation of reactivation, the early genes ( $\alpha$ or $\beta)$ of HSV-1, are expressed. At first, the replication process initiates in the neuron; it then advances from the neuron to the authentic site of infection in the oral epithelial cell nucleus. Thus the same process as the lytic infection is reiterated in the oral epithelium that results in oral lesions and other symptoms $[14,41,54]$. Mostly, DNA replication takes place in viral replication compartments that are located in the nucleus. The first step in this event is assumed to be the cooperation between the viral transcription factor, Infected-cell polypeptide 4 (ICP4) with parental viral genomes [55] (Figure 3).
Recurrent viruses like HSV-1 undergo quite a strategic manner during infection. Therefore, further study on the pathogenesis of the virus should be conducted later on to determine every possible way to prohibit the virus could be understood more precisely. Moreover, it is undoubtedly momentous to understand the process in which the virus lingers in the body life-long for generating more potential treatment strategies to combat the viral infection.

\section{SYMPTOMS AND CLINICAL DELINEATIONS}

Primary infection of HSV-1 usually spreads in the system of the host without showing visible symptoms. But when the immune system initiates suppression of the virus, the symptoms vary from children to adults e.g. formation of blisters around lips or fever usually occurs among children whereas adults may have sore throats or swelling of cervical lymph node $[55,56]$. Symptoms may cling to the patients for up to a couple of weeks and change form through a range of phases. Initially, itching and the inflammation occur at the site of infection which may wind up the formation of blisters or mini-papules around the site of infection [57]. Subsequently, the mini-papules fuse and for the larger blister which is highly itchy and aching either. Thereafter, renewal of the skin takes place beneath the scrabies that result in the formation of Meier complex later on which feels pain and highly itchy as well [58].

Recurrent viruses are sometimes highly critical to be observed because, they can be asymptomatic for weeks to 
Table 2. Tabular representation of the symptoms and clinical representations

\begin{tabular}{|c|c|c|c|}
\hline Phase & Timespan & Symptoms & Reference \\
\hline The latent period & May last from weeks to months & Remains asymptomatic & {$[9,56]$} \\
\hline Premonitory phase & From day 0 to day 1 & Over-itching at the infection site and it becomes reddish. & {$[57]$} \\
\hline Inflammatory response & On day 1 & The infected site swells up and also reddening takes place around this site. & [57] \\
\hline Primary sore & Day 2 and day 3 & $\begin{array}{l}\text { The firm, inflamed mini-papules and blisters are generated. This may tingle } \\
\text { and can cause pain due to touching. Eventually, these blisters containing } \\
\text { fluid, make a cluster on labial tissue of the lip, the intermediate zone } \\
\text { between the lip and skin also called vermilion border, and also can take } \\
\text { place on the cheeks, chin and nasal area. }\end{array}$ & {$[57]$} \\
\hline $\begin{array}{l}\text { Formation of the open } \\
\text { lesion }\end{array}$ & Day 4 & $\begin{array}{l}\text { All the small papules and vesicles crack and fuse to form a huge vesicle } \\
\text { which results in ulcer that weeps clear fluid or blood. Those fluids are } \\
\text { gradually released from the blood vessels and tissues that are inflamed. Two } \\
\text { additional symptoms may also evolve, but it depends on the intensity of the } \\
\text { infection. These are Fever or elevation of body temperature and swollen } \\
\text { lymph gland beneath the jaw. }\end{array}$ & {$[45,59]$} \\
\hline Incrustation & From day 5 to day 8 & $\begin{array}{l}\text { The exudate that has a syrupy thickness, begins to develop a crust that is } \\
\text { golden in color. The blisters ache a lot in this stage. This stage emerges as } \\
\text { the process of healing is begun. However, the fluid that contains the virus } \\
\text { will drip out of blisters or sores through an open crack. }\end{array}$ & {$[45,59]$} \\
\hline The healing phase & From day 9 to 14 & $\begin{array}{l}\text { Renewal of skin cell or new skin formation takes place beneath scabies as } \\
\text { the virus recedes to its latency. Sequentially, lots of scabs will develop over } \\
\text { the sore that further produce the Meier Complex. But these new scabs are } \\
\text { usually tinier than the previous one. At this stage, it's common to feel pain } \\
\text { and itchy. }\end{array}$ & {$[45,59]$} \\
\hline The post-scab phase & From day 12 to 14 & $\begin{array}{l}\text { In the region of viral infection, a reddish area may stick around for a long } \\
\text { time due to the regeneration of the damaged cells. Nonetheless, the release } \\
\text { of successful virus progeny, also known as virus shedding, continues to take } \\
\text { place at this phase. }\end{array}$ & {$[45,59]$} \\
\hline
\end{tabular}

months and the symptoms they create initially after infection, like itching or blister formation, are sometimes ignored by the patients confusing with some allergic reactions or other minor infections. Moreover, further study is needed regarding the characteristics and genetics of HSV-1 to achieve much more precise observation of the clinical representation.

\section{THE IMMUNE RESPONSE OF THE HUMAN BODY AGAINST HSV-1}

Herpes simplex virus causes a variety of illnesses depending on the pathway it enters and the host it's infecting. HSV-1 usually infects the system of a possible host when bodyfluids containing viral load enters through the damage of the skin /mucosa layer, genital tract, and mouth cavity. Then it enters the sensory neuron transport to the dorsal root ganglion by retrograde axonal transport. It develops lifelong latency there[60].

Interferon, macrophages, NK cells, and $\gamma \delta \mathrm{T}$ cells plays vital role in the initial response of the body against HSV [61-63]. The role of interferon (IFN-alpha and beta) in reducing the viral load and protection against HSV has been revealed in murine models. However, toll-like receptors (TLRs) are an important mediator in creating innate immunity against this virus [64]. In general, HSV interacts with both TLR-2 and TLR-9. Interaction with TLR occurs on the surface. Whereas interaction with TLR9 occurs within endosome and particularly of Plasmacytoid DCs [65]. However, this interaction stimulates the production of IFN- $\alpha$, as plasmacytoid DCs are the main effectors of IFN- $\alpha$ production [66].

Besides, the immune system of the body must need to maintain the latency and inhibit the reactivation of the virus. In that case, non-cytolytic CD8+ T cells play crucial rules in producing INF- $\gamma$. These non-cytolytic CD8+ T cells are specific for HSV structural protein and lie in the apposition to neurons. A recent study on the mice model, by knocking out INF- $\gamma$ or addition of INF- $\gamma$ revealed the role of non-cytolytic CD8+ T cells in controlling the viral latency period possibly by inhibiting early viral protein ICPO with the help of CD4+ T cells [67].

In the case of infected epithelium cell, CD4+ T cells secrete IFN- $\gamma$ which restores the major histocompatibility complex (MHC) class I protein expression, thus overcoming the induced blockage of expression of MHC-I by HSV ICP47 and allowing recognition with $\mathrm{CD} 8+$ cytotoxic T cells $[68,69]$. Throughout the lesion, INF- $\gamma$ stimulates MHC class II expression in keratinocytes to recognize by $C D 4+T$ cell. Production of $\beta$ Chemokines, IL-12 and IFN- $\alpha,-\beta,-\gamma$ from hepatic lesion epithelial cell and immune cell play a crucial role in controlling this cytopathic virus $[70,71]$. $\beta$-Chemokines attract monocyte and $T$ cell into the area of the lesion, IL-12 stimulates the secretion of CD4+ in a Th1 pattern which plays a role in activating cytotoxic $T$ cells. Then, CD8+ cytotoxic T cells correspond started to clear the virus from the lesion $[72,73]$ (Figure 4).

When our body cannot defend this virus, symptoms are shown up and infection occurs. That's why much more research needed in this field to explore the mechanism of our body's immune system against this virus to get a clear understanding and accelerate the process of vaccine and antiviral drug development.

\section{GLOBAL SCENARIO OF HSV-1 PREVALENCE}

\section{Europe}

In a serological study conducted in two universities located in Germany and Spain, students (age range between 17-41) were tested for HSV-1 and oral lesions caused by the virus while considering the risk factors like alcohol consumption, coital 


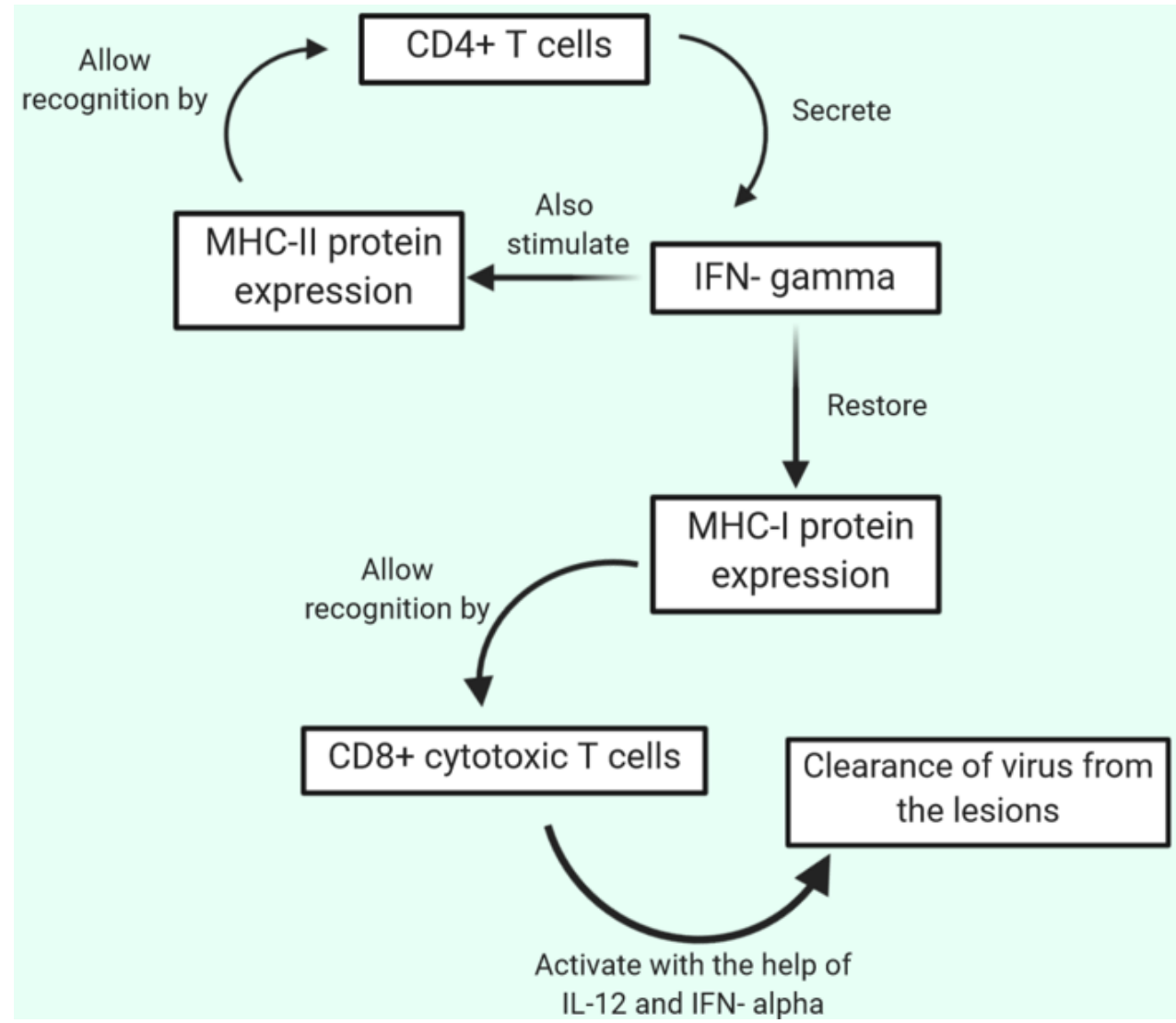

Figure 4. Stimulations of MHC-I \& MHC-Il protein expression by CD4+ T cell and activation of CD8+ cytotoxic T cell with the help of IL-12 and INF-alpha in order to clear the virus from lesions.

activity, hygiene, etc $[74,76]$. In Navarra Public University, Spain 596 students were observed and from University of Bielefeld, Germany 174 students were selected for the assay. Although the sample size differs in the sites, the manifestation result and risk factors were the same for both of them. $55.3 \%$ of the entire sample population tested positive for HSV1 among whom $27.4 \%$ had oral lesions in the 12 months during or before the experiment timeline. As for the risk factor for students who were engaged in unsafe coitus, $95 \%(\mathrm{OR}=1.88, \mathrm{Cl}: 1.31-2.69)$ were prone to contracting the virus. Another study supports this fact as it showed that healthy lifestyle aimed to manage hygiene and specific gender behaviors prevents sexually transmitted diseases (STDs) by $18.2 \%$ in a sample size of 650 students of German universities [76].

The high prevalence of HSV1 in the french population was proved by a study with significance $(p<0.001)$ and $67 \%$ positive result for HSV-1 which was conducted on a sample of 4412 subjects (female $66.5 \%$, males $33.5 \%$ ) $[77,78]$. Indicating that two-thirds of the population was affected by HSV. The study was by an epidemiological inquiry titled HERPIMAX which was a cohort study associated witH SU.VI.MAX [79-81]. Higher seroprevalence was observed among aged groups female however no significant age disparity was observed among men.

\section{North America}

The prevalence in neonates aged two months or lower at the time of experiment in Canada during the period October, 2000 to September, 2003, was reported to be 5.9 per 100,000 live births and among the test subjects, $62.5 \%$ tested positive for HSV-1 [75]. Among the total case, $28.1 \%$ was born prematurely and $24.6 \%$ of the live birth was conducted via cesarean. $51.7 \%$ of the neonates were female and 48.3 of the subjects were male. Another comparison study conducted on genital isolates obtained from the United States tested positive for HSV-1 in 2001, however during 1993 it accounted for 31\% $[80,82,83]$. A nationwide study done in the United States showed a demographic, racial, and gender-based comparison statistical analysis of HSV-1 positive people. The highest rate of prevalence was in the $40-49$ years age range with $59.7 \%$ which is almost twice the population aged 14-19 years as the latter group tested positive for only $27.0 \%$. Females tested positive more than males as the former group is 50.9\% [84] and the latter $45.2 \%$ [85]. Also, seroprevalence for HSV-1 was $53.9 \%$ during 2005-2010 in the United States and among both men and women the rate of infection delined in a continuous manner over the course of two decades $[86,87]$. This gradual infection rate decrease (men $=2.84 \%$ \& women $=2.2 \%$ ) is a significant indicator of the imrpovement of hygiene practice in the population that lowered the transmission of HSV-1 [87].

\section{Asia}

In a prospective study conducted via ELISA using gG1 and gG2 type-specific antigens for samples collected from 463 Bangladeshi female sex workers showed $87.5 \%$ were seropositive for HSV-1 [88]. In an integrated study conducted on samples collected from India, Estonia, Morocco, Brazil, and Sri Lanka. The data of India and Sri Laka indicated that the seropositivity fo $\mathrm{rHSV}-1$ was proportionally linked with the age of the subjects. $31.4 \%$ of the sample from children above or equal to 1 year tested positive for HSV-1 on another hand people aging 45 years and above had $95.5 \%$ seropositivity for HSV-1. In the same study, $82 \%$ of the isolates obtained from 45year or above people tested positive for HSV-1 [89]. Women from Osaka were more prone $(88 \%)$ to the infection than 
Table 3. The identification methods of HSV-1 antibody from serum samples

\begin{tabular}{|c|c|c|c|c|c|}
\hline $\begin{array}{l}\text { Method } \\
\text { name }\end{array}$ & $\begin{array}{l}\text { Commonly used } \\
\text { commercial kit }\end{array}$ & $\begin{array}{l}\text { Type of sample for } \\
\text { test }\end{array}$ & Mechanism & Result output method & Reference \\
\hline $\begin{array}{l}\text { Western } \\
\text { blotting }\end{array}$ & $\begin{array}{l}\text { Euroimmun made } \\
\text { Euroimmun Anti-HSV- } \\
\text { 1/HSV-2 Euroline-WB } \\
\text { (IgM/IgG) }\end{array}$ & Blood serum & $\begin{array}{l}\text { The strips of the kit contain } \\
\text { pure protein and antigenic } \\
\text { mixtures such as gG-1 for HSV- } \\
1 \text { (that is electrophoretically } \\
\text { separated), the antigen binds } \\
\text { with the HSV-1 antibody }\end{array}$ & $\begin{array}{l}\text { The binding percentage depicts } \\
\text { antibody seroprevalence. The strips } \\
\text { are evaluated and interpreted via a } \\
\text { scanner comprising EurolineScan } \\
\text { Software that can measure band } \\
\text { intensity }\end{array}$ & $\begin{array}{l}{[21,34,37,} \\
40,106, \\
107]\end{array}$ \\
\hline $\begin{array}{l}\text { Immunodo } \\
\text { enzyme } \\
\text { assay }\end{array}$ & $\begin{array}{l}\text { HerpeSelect HSV-2 ELISA } \\
\text { IgG or HerpeSelect HSV-1 } \\
\text { ELISA IgG (Conventional) } \\
\text { Previously peroxidase } \\
\text { conjugates were used to } \\
\text { detect HSV-1 antibody [34] }\end{array}$ & Blood serum & $\begin{array}{l}\text { Purified gGC1 antigen located } \\
\text { in the kit identifies and binds } \\
\text { with the antibody of HSV-1 } \\
\text { present in serum or saliva } \\
\text { sample }\end{array}$ & $\begin{array}{l}\text { The ELISA result output was analyzed } \\
\text { by setting the reference standard as } \\
\text { the University of Washington's WB } \\
\text { result to measure specificity, } \\
\text { sensitivity positive predictive value. } \\
\text { SPSS was used to define behavioral } \\
\text { and demographic frequency. }\end{array}$ & $\begin{array}{l}{[21,34,} \\
36,108, \\
109]\end{array}$ \\
\hline $\begin{array}{l}\text { PCR, } \\
\text { RT-PCR }\end{array}$ & $\begin{array}{l}\text { Conventional PCR } \\
\text { machine, Real Time PCR } \\
\text { machine }\end{array}$ & $\begin{array}{l}\text { Periodontal serum, } \\
\text { cutaneous source, } \\
\text { mucocutaneous } \\
\text { source, corneal } \\
\text { impression } \\
\text { membrane }\end{array}$ & $\begin{array}{l}\text { The amplifying primers were } \\
\text { designed to be specific for the } \\
\text { thymidine kinase gene region } \\
\text { of the HSV-1 }\end{array}$ & $\begin{array}{l}\text { The PCR procedure was conducted via } \\
\text { the general method. The statistical } \\
\text { analysis was performed via a } \\
\text { statistical package made for windows } \\
\text { named Statistical package for social } \\
\text { science (SPSS) }\end{array}$ & {$[44,110]$} \\
\hline
\end{tabular}

pregnant women from Tokyo, whose population accounted for $50 \%$. In the diverse demographic group seroprevalence for HSV1 increased steadily with age and relatively higher than HSV2 [90,91]. In Eastern China women were more prone to HSV1 $(94.2 \%)$ than males $(89.1 \%)$ shown in a study conducted on 2141 samples. In the overall tested population, $92.0 \% \mathrm{HSV}$ 1 seroprevalence was present, which was linked to increasing age as well [92]. From a more recent study conducted in the last decade, it was evident that HSV-1 prevalence varies in age group as both males and females of the infected population were among the 20-39 age group (men=68.2\% \& women $=72.6 \%$ ), and infected individuals from older age group were lesser [92,93]. Similar studies from middle east supports the fact that seroprevalence for HSV-1 is linked with increasing age as samples from children under age 10 was lowest at $60.5 \%$, however highest in people over or equal to 30 years (94.3\%) [94, 95].

In retrospect, several woman-oriented studies were done in Bangladesh to observe the HSV-1 prevalence. In one study conducted from 2006 to 2007, 111 pregnant women were tested for the seroprevalence of HSV-1 along with a group of infectious diseases abbreviated as TORCH (Taxoplasma gondii, Rubella, Cytomegalovirus, HSV-1 \&2 ). $90.09 \%$ samples showed HSV-1 antibody presence after being processed by immunoglobin G (IgG) specific ELISA [96]. In 2002, a study focused on the underprivileged sex workers from Dhaka and the severity of HSV-1 among the demographics.. In 1879 women who visited a local healthcare system in Dhaka were tested for multiple sexually transmitted diseases. Among them, $97 \%$ of the tested subjects tested positive for HSV-1 antibody without further observation [97].

\section{Africa}

In Egypt a total of $98 \%$ males aged from 30 to 39 and 100\% males aging 45-49 years were tested positive for HSV-1 [98]. In another study seroprevalence for HSV1 was $98.8 \%$ Moroccan pregnant women [99]. Also, it was reported that the HSV-1 was more prevalent in the older population than younger [100].

\section{South America}

In Natal, Brazil 261 women were tested in a cross-sectional study between January 2000 and December 2003 in a cross- sectional study which showed a higher prevalence of HSV-1 than HSV-2 along with a link of HSV-1 infection rate with age. About $80 \%$ women above 30 years of age tested positive for HSV1 whereas $72 \%$ women tested positive who were less sexually active and above 50 years [101] Supporting evidence of the higher prevalence in Brazil was found as $83.5 \%$ and $63.4 \%$ were found positive in HSV-1 and HSV-2 respectively. [102].

\section{Australia}

In a nationwide study in $1999-2000$, which showed $76 \%$ of the population carrying HSV1 that differed based on age, race, gender [103] Another study indicated the increasing seroprevalence of HSV-1 as in a study combining 25,372 subjects during 1980 and 2003,15.8\% of tested patients were found positive for HSV-1 in 1980, however, $34.9 \%$ were positive in 2003 [104]. Meanwhile in a recent, HSV-1 infection prevalence seems to be higher in female population as a $16 \%$ increasal has occured in 2017 compared to the 45\% female HSV-1 patients observed in the 2004 data obtained from Melbourne Sexual Health Center, Australia [105].

\section{DIAGNOSIS METHODS OF HSV-1 INFECTION}

Identification of the pathogen is vital to initiate treatment procedures as well as for the containment of the virus. Every step of the procedure, from the point of collecting the specimen from a suspected patient to the point of molecular identification of viral DNA in the sample, is essential to prove a medical prognosis when it comes to HSV-1 patients. Using validated commercial kits to conduct molecular identification is a widespread practice around the world. A list of the methods used in previous researches shows that the viral protein structure is the target of most diagnostic medical laboratory kits.

The objective of a comparative review of the listed methods is to help researchers understand the degree of efficiency of each testing method and kits along with probable optimization options regarding sample collection and processing via the test kits. 


\section{CONVENTIONAL TREATMENT METHODS}

As a persistent virus, HSV-1 causes lifetime latency in the host and recurrent labial ulcer lesions occur whenever the virus is reactivated by several factors (eg. radiation, stress, etc). The virus cannot be cured, however proper treatments can lower the degree of the labial lesion and oral infection caused by the viral population. The approaches for preventive measures are aimed to suppress the viral DNA replication either by the admission of nucleoside analogs (eg. Acyclovir or ACV, Acyclovir monophosphate, Acyclovir triphosphate valacyclovir, penciclovir) or helicase primase inhibitors (eg. Amenamevir. Pritelivir) [111-113]. The guanosine analog ACV is phosphorylated when the $\beta$ gene of HSV synthesizes thymidine kinase and the activation of the topical drug leads to viral replication suppression [114]. Although reduction of the lesion was successfully done by ACV, its limitations are eradicated by prodrugs like valacyclovir and penciclovir. The latter has longer intracellular half-life post phosphorylation by thymidine kinase $[113,115]$. In contrast, valacyclovir can be used as a short term remedy for the genital lesion caused by HSV-1 $[112,116]$. After long term application of the acyclovir (ACV) topical ointment, the HSV-1 may show some degrees of resistance or give rise to resistant strain $[117,118]$. To remedy this problem, the activity of 9-(4-hydroxy-3-hydroxymethyl but-1-yl) guanine otherwise known as BRL against HSV-1 can be utilized that show thymidine kinase activity in few of its mutant form that shows resistance against ACV [118]. Natural resources have also been explored to find a possible treatment by external application such as the Houttuynia cordata containing anti-inflammatory activity [119-121]. Despite relieving irritation and degree of the lesion the natural resources show little replication inhibitory activities.

In the past decade, anti-viral vaccine development has been the focus of the preventive measure against HSV as the virus cannot be terminated once acquired and let to replicate inside the human system.

\section{PROGRESSES IN HSV-1 VACCINE DEVELOPMENT}

The vaccine is an acquired immunity stimulatory substance which is usually developed to make the physiological system ready to fight against one or multiple diseases. This may contain a weaker form of the causative disease agent, its substituent, mutant form its protein product, etc. Vaccines are usually developed for two purposes. One is for prevention and another one is for treatment. A preventive vaccine, in the case of HSV-1, generally produces a high rate of the immune response against HSV-1 before get infected and creates high immunity to prevent secondary infection at high-risk populations. Whereas, Therapeutic vaccine for HSV-1, injected into a seropositive person who is infected by this virus before. This vaccine reduces the severity of disease and creates immunity against this pathogen [122].

Many vaccine candidates with a diverse platform have been studied in the preclinical phase, some of them are tested in clinical trials and early developmental stages with the financial help of government, Academic, Biotech institutions and several pharmaceutical companies are also seen to invest on it.
The most widely used vaccine for the human clinical trial is the Glycoprotein subunit vaccine, which is produced by mutating gD gene at amino acid residues 3 and 38 by altering alanine with cysteine and tyrosine with cysteine. This impaired mutant vaccine can't get entry and create a huge immune response. Thus it is a novel candidate attenuated live HSV-1 vaccine [123]. The largest clinical trial occurs the subunit vaccine Herpevac in seronegative women which contain glycoprotein-2 (gD2) with alum/MPL adjuvant (Table 4) [124].

HSV529 a replication-defective, live attenuated virus deleted in gD2 enters into the Phase I trial for both preventive and therapeutic indications. It is the first developed virus to eliminate latency from the dorsal root ganglia [131]. Some vaccine candidates have entered into phase I/II trial within few years (Table 4). These candidates have a novel stimulatory effect on T cell immunity. The GEN-003 which is a gD2/ICP4 protein subunit-containing vaccine with adjuvant of Matrix $M$ has shown to $50 \%$ decline in Genital HSV shedding in primary trial results [127]. However novel delivery methods for glycoprotein $D$ and intranasal delivery methods are being explored. Besides glycoprotein candidates with unique features are still being investigated. For instance, the trivalent vaccine containing $\mathrm{gD} / \mathrm{gC} / \mathrm{gE}$ glycoprotein in promising in mice [132]. There is also some latest work are performing in the field of vaccine development. To inhibit the corneal blindness, a prophylactic live attenuated vaccine is developed which successfully able to protect the ocular HSV-1 challenged in mice. This vaccine involved a T-dependent hormonal immune response and complement C3. Most importantly it works without doing any harm to eye [142]. Besides, a trial was conducted to analyze the efficacy of the Glycoprotein D dependent HSV vaccine and it was found that it shows $73 \%$ and $74 \%$ efficacy in women. But in the case of men, it shows no effect [143]. Again, to control HSV, a mutant virus was created where the glycoprotein $\mathrm{H}(\mathrm{gH})$ gene was deleted. As a result, the virus cannot perform a multi-cell cycle. It just able to continue one cycle and after that, it will disable. After insertion in the guinea pig, it was seen to increase the high degree of preventions against HSV-2, genital herpes, and observed to significantly reduce the recurrent infections [144]. Moreover, A improved recombinant strain is produced, CJ83193- like recombinant CJ9-gD, which has the deletions of an essential gene and contains an extra copy of the gene responsible for encoding glycoprotein $\mathrm{D}(\mathrm{gD})$. Mice immunized with CJ9-gD produce 3.5 fold higher HSV-1 neutralizing antibody and produce a strong HSV-1 T cell response and $80 \%$ reduction of the latent infection by HSV-1 wild type strain [145]. Lastly, a mammalian cell line constructed which secreted a soluble gHgL complex, consisting of gH truncated at amino acid 792 and the full length of $\mathrm{gL}$. To test its potentiality as a subunit vaccine, $\mathrm{BALB} / \mathrm{c}$ mice were immunized with the complex, and the result was observed that the mice model shows a high level of virusneutralizing activity, reduced primary lesions and show no secondary zosteriform lesions [146].

As evident in the global prevalence article of the review, more than one-third of the world's population shows some degree of HSV-1 symptoms. Meaning that the possible carriers of the recurrent virus which will have until decease and will be able to transmit it to a non-healthy person. The current treatment methods are neither able to inhibit the recurrency of the pathogenic actions of HSV-1 nor they can ensure complete inhibition when a non-infected person is exposed to the virus. HSV-1 poses are fatal pathogens when it creates major organ- 
Table 4. All possible kinds of vaccines for HSV-1 that are under development and research in pre-clinical and post clinical trials. Here, $X$ sign states on which phase the vaccine is now on; $X(T), X(P)$, and $X(P \& T)$ sign refers to either the vaccine is therapeutic types, preventive types, or both respectively; POC refers as Proof of Concept Trial.

\begin{tabular}{|c|c|c|c|c|c|c|c|}
\hline $\begin{array}{c}\text { Candidate name or } \\
\text { Identifier }\end{array}$ & $\begin{array}{c}\text { Institutions/ } \\
\text { Company }\end{array}$ & Platforms /Antigens & $\begin{array}{l}\text { Pre- } \\
\text { clinical }\end{array}$ & Phase I & Phase II & POC & Phase III References \\
\hline $\begin{array}{c}\text { GEN-003 } \\
\text { (gD2/ICP4/MM } \\
\text { adjuvant) } \\
\end{array}$ & $\begin{array}{c}\text { Genocea } \\
\text { Biosciences }\end{array}$ & $\begin{array}{c}\text { Subunit vaccine: gD2/ICP4 with Matrix M2 } \\
\text { adjuvant }\end{array}$ & & & $X(T)$ & $x$ & $\begin{array}{l}{[125,126,} \\
127]\end{array}$ \\
\hline HerpV & Agenus & $\begin{array}{c}32 \text { 35-mer peptides, complexed with } \\
\text { HSP, QS-21 Adjuvant }\end{array}$ & & & $X(T)$ & & {$[128]$} \\
\hline $\begin{array}{l}\text { Codon optimized } \\
\text { polynucleotide } \\
\text { vaccine } \\
\end{array}$ & Admedus & $\begin{array}{l}\text { DNA vaccine-gD2 codon } \\
\text { optimized/ubiquitin-tagged }\end{array}$ & & & $X(T)$ & & [129] \\
\hline VCL-HB01/HM01 & Vical & DNA vaccine: gD2+/-UL46/Vaxfectin & & & $X(T)$ & & {$[130]$} \\
\hline HSV529 & Sanofi & $\begin{array}{c}\text { Replication-defective HSV-2 with } \\
\text { deletions of UL5 and UL29 }\end{array}$ & & $X(P \& T)$ & & & {$[131]$} \\
\hline gD2/gC2/gE2 & $\begin{array}{c}\text { Perelman School of } \\
\text { Medicine at the } \\
\text { University of } \\
\text { Pennsylvania }\end{array}$ & Subunit vaccine: gD2/gC2/gE2 & $x$ & & & & {$[132]$} \\
\hline HSV-2 $0 \Delta N L S$ & Rational Vaccines & $\begin{array}{c}\text { Live, attenuated replication-competent } \\
\text { HSV-2 with deletion of ICPO }\end{array}$ & $x$ & & & & [133] \\
\hline HF10 & & $\begin{array}{c}\text { Live, attenuated replication-competent } \\
\text { HSV-1 mutated for UL43, UL49.5, UL55, } \\
\text { UL56, LAT }\end{array}$ & $x$ & & & & {$[134]$} \\
\hline$\Delta \mathrm{gD} 2$ & $\begin{array}{c}\text { Albert Einstein } \\
\text { College of Medicine }\end{array}$ & Live, attenuated HSV-2 deleted in gD2 & $x$ & & & & {$[135]$} \\
\hline AD472 & MedImmune & $\begin{array}{c}\text { HSV-2 mutated for g34.5, UL43.5, UL55- } \\
56, \text { US10, US11, US12 }\end{array}$ & $x$ & & & & {$[136]$} \\
\hline CJ2-gD2 & & Non-replicating gD2 dominant neg HSV-2 & $\mathrm{X}$ & & & & {$[137]$} \\
\hline Prime-pull strategy & & $\begin{array}{l}\text { "Prime" with live attenuated HSV-2 } \\
\text { followed by "pull" with topical } \\
\text { intravaginal CXCL9/CXCL10 chemokine }\end{array}$ & $x$ & & & & [138] \\
\hline $\begin{array}{l}\text { Inactivated HSV-2 in } \\
\text { MPL/alum }\end{array}$ & $\begin{array}{l}\text { Spector, University } \\
\text { of California San } \\
\text { Diego }\end{array}$ & $\begin{array}{l}\text { with topical intravaginal CXCL9/CXCL10 } \\
\text { chemokine Formalin inactivated HSV-2 }\end{array}$ & $x$ & & & & [139] \\
\hline $\begin{array}{l}\text { HSV-1 glycoprotein B } \\
\text { lentiviral vector }\end{array}$ & & Lentiviral vector expressing gB1 & $x$ & & & & {$[140]$} \\
\hline gB1s-NISV & & $\begin{array}{c}\text { Intranasal non-ionic surfactant vesicles } \\
\text { containing recombinant HSV-1 gB }\end{array}$ & $x$ & & & & {$[141]$} \\
\hline
\end{tabular}

related complications therefore immunity against it via vaccination will be vital to control it and lower the range of transmission. Such a vaccine can annihilate the virus to some degree in the same manner as Poliovirus has been suppressed in the last century.

\section{CURRENT STATUS AND FUTURE PROSPECTS OF HSV-1 RESEARCH}

According to the World Health Organization, about 417 million people in the world age ranging from 15-49 are affected by HSV-1 [147]. In most cases, people affected by it without showing any symptoms. Sometimes it may cause many acute complications such as corneal keratitis, nerve damage \& may lead to azimuthal disease [148]. Researchers are working hard to find out the solutions of HSV-1. A good deal of researches is conducting with the funding of government, non-government research institutes, renowned universities, different pharmaceuticals and vaccine developing companies, etc.

Nowadays, scientists are working hard to discover effective anti-viral agents against HSV-1. As of this investigation, bioactive materials extracted by enzyme assisted hydrolysis from C. crispus (multiaxial filamentous tissue) and C. fragile (coenocytic tissue) exhibits anti-viral activity without creating any kind of cytotoxicity [149]. Besides, Chlorogenic acid (CGA) is found to obstruct the inflammatory reaction that occurs in HSV by suppressing Toll-like receptor (TLR)-2 \& TLR9-Myd88 signaling pathways [150]. Moreover, the Researcher's found geopropolis from Scaptotrigona postica as an anti-viral agent against HSV [151]. Furthermore, another group of scientists found Polyphenol rich extract, from natural shelled (NPRE) pistachios kernels (Pistacia vera L.) which have a remarkable inhibitory activity against HSV-1 [152]. Also, Arisaema tortuosum extracts Apigenin and luteolin demonstrate antiviral activity and successfully able to reduce virus progeny. Further, a compound name apigenin is found to create obstacles in the cell to cell virus spread [153]. Research on Aspergillipeptide D revealed that though it doesn't interrupt in HSV-1 viral infection stages but dramatically it reduces both gene and protein levels including viral late protein $\mathrm{gB}$ and found to suppress its location on endoplasmic reticulum and Golgi apparatus [154]. Besides, Omeprazole was found to increase the anti-cancer effect of nucleoside analog 5-fluorouracil without affecting ribavirin in nontoxic concentration (up to 80 $\mathrm{mg} / \mathrm{mL}$ ). Instead, it enhances the acyclovir-mediated effect on HSV-1 \& 2 [155]. Moreover, a newly synthesized compound 2pyrimidyl benzothiazole derivatives exhibit antiviral activities and inhibitory effect on Hsp90a protein. Thus, it has the potential to use as an effective broad-spectrum antiviral agent [156]. 
The development of advanced-level sequencing technique by $4 \mathrm{sU}$ tagging could lead to analyze real-time changes in RNA synthesis, processing, and translation at transcriptome level and could explore what type of changes occurring when a cell is infected by pathogens like HSV-1 [157]. Besides, an investigation found that HSV-1 \& HSV-2 exhibit species specific modulation in programmed necrosis with the help of Viral Ribonucleotide Reductase Large Subunit R1. In mouse cell, it is found to directly activating programmed necrosis where as in human, it is blocked TNF (Tumor necrosis factor) induced necrosis by obstructing the induction of receptor interacting protein kinase-1 (RIP1) / receptor interacting protein kinase-3 (RIP3) necrosome [158].

\section{CONCLUSION}

HSV-1 continues to spread among different risk groups and possesses major threat to the global population. So far, proper hygiene, social ethical values and religious practices appear to be the most effective strategies to reduce the transmission of HSV-1. However, no approved licensed vaccines are currently available in the market to counter the HSV-1 infection and spread. Therefore, researchers are working hard to find out clinical solutions for HSV-1. Extensive epidemiological and genomic studies are also required to accelerate the process of vaccine development. Better further understanding of the pathogenesis with combining existing information and initiating further experiments can aid the chances of obtaining antiviral drugs with high efficacy to treat the infected patients. As a result, further researches and specific trials are warranted to combat worldwide HSV-1 infection.

Author contributions: $\mathrm{MU}$ and $\mathrm{YA}$ conceived and designed the study. AM, SR and AC wrote the draft manuscript. MU, YA and BS edited the draft manuscript and assisted in formatting. MU and AS revised the final version. AS supervised the study. All authors approved the final manuscript for publication

Funding: The authors didn't receive funding from internal or external sources.

Declaration of interest: The authors declare no conflict of interest regarding the publication of the manuscript.

Acknowledgements: Authors acknowledge the members of Swift Integrity Computational Lab, Dhaka, Bangladesh, a virtual platform of young researchers for their support during the preparation of the manuscript.

\section{REFERENCES}

1. Arvin AM. Overview of Classification. Essay. In Human Herpesviruses: Biology, Therapy and Immunoprophylaxis. Cambridge: Cambridge University Press, 2007. https://doi.org/10.1017/CB09780511545313

2. Crimi S, Fiorillo L, Bianchi A, D'Amico C, Amoroso G, Gorassini F, Mastroieni R, Marino S, Scoglio C, Catalano F, Campagna P. Herpes Virus, Oral Clinical Signs and QoL: Systematic Review of Recent Data. Viruses. 2019 May;11(5):463.10. Caspermeyer J. Herpes STDs: From Chimps to Humans to Cold Sore Cousin Mixing Before Worldwide Spread. https://doi.org/10.3390/v11050463 PMid:31117264 PMCid:PMC6563194
3. Zmasek CM, Knipe DM, Pellett PE, Scheuermann RH. Classification of human Herpesviridae proteins using Domain-architecture Aware Inference of Orthologs (DAIO). Virology. 2019 Mar 1;529:29-42. https://doi.org/10.1016/ j.virol.2019.01.005 PMid:30660046 PMCid:PMC6502252

4. Albà MM, Das R, Orengo CA, Kellam P. Genomewide function conservation and phylogeny in the Herpesviridae. Genome research. 2001 Jan 1;11(1):43-54. https://doi.org/10.1101/gr.149801 PMid:11156614 PMCid: PMC311046

5. Davison AJ. Herpesvirus systematics. Veterinary microbiology. 2010 Jun 16;143(1):52-69. https://doi.org/ 10.1016/j.vetmic.2010.02.014 PMid:20346601 PMCid: PMC2995426

6. Leung AK, Barankin B. Herpes labialis: an update. Recent patents on inflammation \& allergy drug discovery. 2017 Oct 1;11(2):107-13. https://doi.org/10.2174/1872213X1166617 1003151717 PMid:28971780

7. Opstelten W, Neven AK, Eekhof J. Treatment and prevention of herpes labialis. Canadian Family Physician. 2008 Dec 1;54(12):1683-7.

8. Embil JA, Stephens RG, Manuel FR. Prevalence of recurrent herpes labialis and aphthous ulcers among young adults on six continents. Canadian Medical Association Journal. 1975 Oct 4;113(7):627.

9. Spruance SL, Nett R, Marbury T, Wolff R, Johnson J, Theodore Spaulding for The Acyclovir Cream Study Group. Acyclovir cream for treatment of herpes simplex labialis: results of two randomized, double-blind, vehiclecontrolled, multicenter clinical trials. Antimicrobial agents and chemotherapy. 2002 Jul 1;46(7):2238-43. https://doi.org/10.1128/AAC.46.7.2238-2243.2002 PMid:12069980 PMCid:PMC127288

10. Sarnoff DS. Treatment of recurrent herpes labialis. Journal of drugs in dermatology: JDD. 2014 Sep;13(9):1016.

11. Van der Linden MW, Westert GP, De Bakker DH, Schellevis FG. Second national study into diseases and actions in general practice. Utrecht, Bilthoven: Netherlands Institute for Health Services Research (NIVEL), National Institute of Public Health and the Environment (RIVM). 2004.

12. Armangue T, Spatola M, Vlagea A, Mattozzi S, CárcelesCordon M, Martinez-Heras E, Llufriu S, Muchart J, Erro ME, Abraira L, Moris G. Frequency, symptoms, risk factors, and outcomes of autoimmune encephalitis after herpes simplex encephalitis: a prospective observational study and retrospective analysis. The Lancet Neurology. $2018 \mathrm{Sep}$ 1;17(9):760-72.

13. Saleh D, Sharma S. Herpes Simplex Type 1. InStatPearls 2019. StatPearls Publishing.

14. Koujah L, Suryawanshi RK, Shukla D. Pathological processes activated by herpes simplex virus-1 (HSV-1) infection in the cornea. Cellular and molecular life sciences. 2019 Feb 15;76(3):405-19. https://doi.org/10.1007/s00018018-2938-1 PMid:30327839 PMCid:PMC6349487

15. Underdown SJ, Kumar K, Houldcroft C. Network analysis of the hominin origin of Herpes Simplex virus 2 from fossil data. Virus evolution. 2017 Jul;3(2):vex026. https://doi.org/ 10.1093/ve/vex026 PMid:28979799 PMCid:PMC5617628

16. Kitchen A, Shackelton LA, Holmes EC. Family level phylogenies reveal modes of macroevolution in RNA viruses. Proceedings of the National Academy of Sciences. 2011 Jan 4;108(1):238-43. https://doi.org/10.1073/ pnas. 1011090108 PMid:21173251 PMCid:PMC3017157 
17. Wertheim JO, Smith MD, Smith DM, Scheffler K, Kosakovsky Pond SL. Evolutionary origins of human herpes simplex viruses 1 and 2. Molecular biology and evolution. $2014 \mathrm{Sep}$ 1;31(9):2356-64. https://doi.org/10.1093/molbev/msu185 PMid:24916030 PMCid:PMC4137711

18. Patterson N, Richter DJ, Gnerre S, Lander ES, Reich D. Genetic evidence for complex speciation of humans and chimpanzees. Nature. 2006 Jun;441(7097):1103-8. https://doi.org/10.1038/nature04789 PMid:16710306

19. McGeoch DJ, Cook S, Dolan A, Jamieson FE, Telford EA. Molecular phylogeny and evolutionary timescale for the family of mammalian herpesviruses. Journal of molecular biology. 1995 Mar 31;247(3):443-58. https://doi.org/ 10.1006/jmbi.1995.0152 PMid:7714900

20. Luebcke E, Dubovi E, Black D, Ohsawa K, Eberle R. Isolation and characterization of a chimpanzee alphaherpesvirus. Journal of General Virology. 2006 Jan 1;87(1):11-9. https://doi.org/10.1099/vir.0.81606-0 PMid:16361413

21. Norberg P, Tyler S, Severini A, Whitley R, Liljeqvist JÅ, Bergström T. A genome-wide comparative evolutionary analysis of herpes simplex virus type 1 and varicella zoster virus. PloS one. 2011 Jul 25;6(7):e22527. https://doi.org/ 10.1371/journal.pone.0022527 PMid:21799886 PMCid: PMC3143153

22. Aloyouny AY, Albagieh $\mathrm{HN}, \mathrm{Al}-\mathrm{Serwi} \mathrm{RH}$. Oral and perioral herpes simplex virus infection type I in a five-month-old infant: A case report. World Journal of Clinical Cases. 2021 Jan 26;9(3):685. https://doi.org/10.12998/wjcc.v9.i3.685 PMid:33553409 PMCid:PMC7829727

23. Vergou T. Herpes Simplex Virus Infection (Orofacial). InEuropean Handbook of Dermatological Treatments 2015 (pp. 373-377). Springer, Berlin, Heidelberg. https://doi.org/10.1007/978-3-662-45139-7_38

24. Pinninti SG, Kimberlin DW. Neonatal herpes simplex virus infections. InSeminars in perinatology 2018 Apr 1 (Vol. 42, No. 3, pp. 168-175). WB Saunders. https://doi.org/ 10.1053/j.semperi.2018.02.004 PMid:29544668

25. Patton ME, Bernstein K, Liu G, Zaidi A, Markowitz LE. Seroprevalence of herpes simplex virus types 1 and 2 among pregnant women and sexually active, nonpregnant women in the United States. Clinical Infectious Diseases. 2018 Oct 30;67(10):1535-42. https://doi.org/10.1093/ cid/ciy318 PMid:29668856 PMCid:PMC6369524

26. Vyse AJ, Gay NJ, Slomka MJ, Gopal R, Gibbs T, MorganCapner P, Brown DW. The burden of infection with HSV-1 and HSV-2 in England and Wales: implications for the changing epidemiology of genital herpes. Sexually transmitted infections. 2000 Jun 1;76(3):183-7. https://doi.org/10.1136/sti.76.3.183 PMid:10961195 PMCid: PMC1744133

27. Hogestyn JM, Mock DJ, Mayer-Proschel M. Contributions of neurotropic human herpesviruses herpes simplex virus 1 and human herpesvirus 6 to neurodegenerative disease pathology. Neural regeneration research. 2018 Feb;13(2):211. https://doi.org/10.4103/1673-5374.226380 PMid:29557362 PMCid:PMC5879884

28. Freifeld AG, Hilliard J, Southers J, Murray M, Savarese B, Schmitt JM, Straus SE. A controlled seroprevalence survey of primate handlers for evidence of asymptomatic herpes $B$ virus infection. Journal of Infectious Diseases. $1995 \mathrm{Apr}$ 1;171(4):1031-4. https://doi.org/10.1093/infdis/171.4.1031 PMid:7706783
29. Elmore D, Eberle R. Monkey B virus (Cercopithecine herpesvirus 1). Comparative medicine. 2008 Feb 1;58(1):1121.

30. Hilliard J. Monkey B virus. Human herpesviruses: biology, therapy, and immunoprophylaxis. Cambridge: Cambridge University Press; 2007.

31. Severini A, Tyler SD, Peters GA, Black D, Eberle R. Genome sequence of a chimpanzee herpesvirus and its relation to other primate alphaherpesviruses. Archives of virology. 2013 Aug 1;158(8):1825-8. https://doi.org/10.1007/s00705013-1666-y PMid:23508549 PMCid:PMC5874796

32. Eberle R, Black DH, Lipper S, Hilliard JK. Herpesvirus papio 2 , an SA8-like $\alpha$-herpesvirus of baboons. Archives of virology. 1995 Mar 1;140(3):529-45. https://doi.org/ 10.1007/BF01718429 PMid:7733825

33. Clarkson MJ, Thorpe E, McCarthy K. A virus disease of captive vervet monkeys (Cercopithecus aethiops) caused by a new herpesvirus. Archiv für die gesamte Virusforschung. 1967 Mar 1;22(1-2):219-34. https://doi.org/ 10.1007/BF01240517 PMid:4301195

34. Lee MH, Rostal MK, Hughes T, Sitam F, Lee CY, Japning J, Harden ME, Griffiths A, Basir M, Wolfe ND, Epstein JH. Macacine herpesvirus 1 in long-tailed macaques, Malaysia, 2009-2011. Emerging infectious diseases. 2015 Jul;21(7):1107. https://doi.org/10.3201/eid2107.140162 PMid:26080081 PMCid:PMC4480374

35. Tyler S, Severini A, Black D, Walker M, Eberle R. Structure and sequence of the saimiriine herpesvirus 1 genome. Virology. 2011 Feb 5;410(1):181-91. https://doi.org/10.1016 /j.virol.2010.11.008 PMid:21130483 PMCid:PMC3017652

36. Eberle R, Jones-Engel L. Understanding primate herpesviruses. Journal of emerging diseases and virology. 2017 Mar;3(1). https://doi.org/10.16966/2473-1846.127 PMid:29607423 PMCid:PMC5878061

37. Chemaitelly H, Nagelkerke N, Omori R, Abu-Raddad LJ. Characterizing herpes simplex virus type 1 and type 2 seroprevalence declines and epidemiological association in the United States. PloS one. 2019 Jun 6;14(6):e0214151. https://doi.org/10.1371/journal.pone.0214151 PMid:31170140 PMCid:PMC6553692

38. Fleming DT, McQuillan GM, Johnson RE, Nahmias AJ, Aral SO, Lee FK, St. Louis ME. Herpes simplex virus type 2 in the United States, 1976 to 1994. New England Journal of Medicine. 1997 Oct 16;337(16):1105-11. https://doi.org/ 10.1056/NEJM199710163371601 PMid:9329932

39. Melendez LV, Hunt RD, King NW, Barahona HH, Daniel MD, Fraser CE, Garcia FG. Herpesvirus ateles, a new lymphoma virus of monkeys. Nature New Biology. 1972 Feb 9;235(58):182-4. https://doi.org/10.1038/newbio235182b0 PMid:4621875

40. Mody PH, Pathak S, Hanson LK, Spencer JV. Herpes Simplex Virus: A Versatile Tool for Insights Into Evolution, Gene Delivery, and Tumor Immunotherapy. Virology: Research and Treatment. 2020 May;11:1178122X20913274. https://doi.org/10.1177/1178122X20913274

41. Brown JC. Herpes simplex virus latency: the DNA repaircentered pathway. Advances in virology. 2017;2017. https://doi.org/10.1155/2017/7028194 PMid:28255301 PMCid:PMC5309397

42. Bloom DC. Alphaherpesvirus latency: a dynamic state of transcription and reactivation. InAdvances in virus research 2016 Jan 1 (Vol. 94, pp. 53-80). Academic Press. https://doi.org/10.1016/bs.aivir.2015.10.001 PMid:26997590 
43. Thellman NM, Triezenberg SJ. Herpes simplex virus establishment, maintenance, and reactivation: in vitro modeling of latency. Pathogens. 2017 Sep;6(3):28. https://doi.org/10.3390/pathogens6030028 PMid:28644417 PMCid:PMC5617985

44. Whitley RJ. The epidemiology and clinical manifestations of herpes simplex virus infections. The human herpesviruses. 1993;69.

45. Bruce AJ, Rogers III RS. Oral manifestations of sexually transmitted diseases. Clinics in dermatology. 2004 Nov 1;22(6):520-7. https://doi.org/10.1016/j.clindermatol.2004. 07.005 PMid:15596324

46. Karaba AH, Kopp SJ, Longnecker R. Herpesvirus entry mediator and nectin-1 mediate herpes simplex virus 1 infection of the murine cornea. Journal of virology. 2011 Oct 1;85(19):10041-7. https://doi.org/10.1128/JVI.05445-11 PMid:21795335 PMCid:PMC3196397

47. Connolly SA, Jackson JO, Jardetzky TS, Longnecker R. Fusing structure and function: a structural view of the herpesvirus entry machinery. Nature reviews Microbiology. 2011 May;9(5):369-81. https://doi.org/10.1038/nrmicro 2548 PMid:21478902 PMCid:PMC3242325

48. Reske A, Pollara G, Krummenacher C, Chain BM, Katz DR. Understanding HSV-1 entry glycoproteins. Reviews in medical virology. 2007 May;17(3):205-15. https://doi.org/ 10.1002/rmv.531 PMid:17295428 PMCid:PMC7169067

49. Alandijany T, Roberts AP, Conn KL, Loney C, McFarlane S, Orr A, Boutell C. Distinct temporal roles for the promyelocytic leukaemia (PML) protein in the sequential regulation of intracellular host immunity to HSV-1 infection. PLoS pathogens. 2018 Jan;14(1). https://doi.org/ 10.1371/journal.ppat.1006769 PMid:29309427 PMCid: PMC5757968

50. Mastrolorenzo A, Giomi B, Tiradritti L, Zuccati G. Oral manifestations of sexually transmitted infections. Giornale italiano di dermatologia e venereologia: organo ufficiale, Societa italiana di dermatologia e sifilografia. 2012 Aug;147(4):373-88.

51. Nicoll MP, Proença JT, Efstathiou S. The molecular basis of herpes simplex virus latency. FEMS microbiology reviews. 2012 May 1;36(3):684-705. https://doi.org/10.1111/j.15746976.2011.00320.x PMid:22150699 PMCid:PMC3492847

52. Cook ML, Stevens JG. Pathogenesis of herpetic neuritis and ganglionitis in mice: evidence for intra-axonal transport of infection. Infection and Immunity. 1973 Feb 1;7(2):272-88. https://doi.org/10.1128/IAl.7.2.272-288.1973 PMid:4348966 PMCid:PMC422671

53. Davis CP. Oral Herpes (Cold Sores) Symptoms, Treatment, Testing \& Pictures. eMedicineHealth. eMedicineHealth; 2019. Available at: https://www.emedicinehealth.com/ oral_herpes/article_em.htm\#oral_herpes_hsv-1_herpes_ simplex_virus-1_facts (Accessed: 15 April 2020).

54. Knipe DM, Howley P. Fields virology. Lippincott Williams \& Wilkins; 2013 May 21.

55. Grondin B, DeLuca N. Herpes simplex virus type 1 ICP4 promotes transcription preinitiation complex formation by enhancing the binding of TFIID to DNA. Journal of virology. 2000 Dec 15;74(24):11504-10. https://doi.org/10.1128/JVI. 74.24.11504-11510.2000 PMid:11090147 PMCid:PMC112430

56. Opstelten W, Neven AK, Eekhof J. Treatment and prevention of herpes labialis. Canadian Family Physician. 2008 Dec 1;54(12):1683-7.
57. Emmert DH. Treatment of common cutaneous herpes simplex virus infections. American family physician. 2000 Mar 15;61(6):1697-704.

58. Johnston G, Sladden M. Scabies: diagnosis and treatment. Bmj. 2005 Sep 15;331(7517):619-22. https://doi.org/ 10.1136/bmj.331.7517.619 PMid:16166133 PMCid: PMC1215558

59. Sucato G, Wald A, Wakabayashi E, Vieira J, Corey L. Evidence of latency and reactivation of both herpes simplex virus (HSV)-1 and HSV-2 in the genital region. Journal of Infectious Diseases. 1998 Apr 1;177(4):1069-72. https://doi.org/10.1086/515261 PMid:9534984

60. Whitley RJ, Roizman B. Herpes simplex virus infections. The lancet. 2001 May 12;357(9267):1513-8. https://doi.org/ 10.1016/S0140-6736(00)04638-9

61. Hendricks RL, Weber PC, Taylor JL, Koumbis A, Tumpey TM, Glorioso JC. Endogenously produced interferon a protects mice from herpes simplex virus type 1 corneal disease. Journal of general virology. 1991 Jul 1;72(7):1601-10. https://doi.org/10.1099/0022-1317-72-7-1601 PMid: 1649898

62. Amin I, Younas S, Afzal S, Shahid M, Idrees M. Herpes simplex virus type 1 and host antiviral immune responses: an update. Viral immunology. 2019 Dec 1;32(10):424-9. https://doi.org/10.1089/vim.2019.0097 PMid:31599707

63. Cheng H, Tumpey TM, Staats HF, van Rooijen N, Oakes JE, Lausch RN. Role of macrophages in restricting herpes simplex virus type 1 growth after ocular infection. Investigative ophthalmology \& visual science. 2000 May $1 ; 41(6): 1402-9$.

64. Finberg RW, Kurt-Jones EA. Viruses and Toll-like receptors. Microbes and infection. 2004 Dec 1;6(15):1356-60. https://doi.org/10.1016/j.micinf.2004.08.013 PMid:15596120

65. Lund J, Sato A, Akira S, Medzhitov R, Iwasaki A. Toll-like receptor 9-mediated recognition of Herpes simplex virus-2 by plasmacytoid dendritic cells. The Journal of experimental medicine. 2003 Aug 4;198(3):513-20. https://doi.org/10.1084/jem.20030162 PMid:12900525 PMCid:PMC2194085

66. Kibata K, Ito $\mathrm{T}$, Inaba M, Tanaka A, Iwata R, InagakiKatashiba N, Phan V, Satake A, Nomura S. The immunomodulatory-drug, lenalidomide, sustains and enhances interferon- $\alpha$ production by human plasmacytoid dendritic cells. Journal of blood medicine. 2019;10:217. https://doi.org/10.2147/JBM.S206459 PMid:31372079 PMCid:PMC6635835

67. Khanna KM, Lepisto AJ, Decman V, Hendricks RL. Immune control of herpes simplex virus during latency. Current opinion in immunology. 2004 Aug 1;16(4):463-9. https://doi.org/10.1016/j.coi.2004.05.003 PMid:15245740

68. Praest $P$, Liaci AM, Förster F, Wiertz EJ. New insights into the structure of the MHC class I peptide-loading complex and mechanisms of TAP inhibition by viral immune evasion proteins. Molecular immunology. 2019 Sep 1;113:103-14. https://doi.org/10.1016/j.molimm.2018.03.020 PMid:29606337

69. Mikloska Z, Kesson AM, Penfold ME, Cunningham AL. Herpes simplex virus protein targets for CD4 and CD8 lymphocyte cytotoxicity in cultured epidermal keratinocytes treated with interferon- $\gamma$. The Journal of infectious diseases. 1996 Jan 1;173(1):7-17. https://doi.org/10.1093/infdis/173.1.7 PMid:8537685 
70. Huang R, Wu J, Zhou X, Jiang H, Zhou GG, Roizman B. Herpes simplex virus 1 microRNA miR-H28 exported to uninfected cells in exosomes restricts cell-to-cell virus spread by inducing gamma interferon mRNA. Journal of virology. 2019 Nov 1;93(21). https://doi.org/10.1128/ JVI.01005-19 PMid:31413129 PMCid:PMC6803268

71. Bauer D, Alt M, Dirks M, Buch A, Heilingloh CS, Dittmer U, Giebel B, Görgens A, Palapys V, Kasper M, Eis-Hübinger AM. $A$ therapeutic antiviral antibody inhibits the anterograde directed neuron-to-cell spread of herpes simplex virus and protects against ocular disease. Frontiers in microbiology. 2017 Oct 31;8:2115. https://doi.org/10.3389/ fmicb.2017.02115 PMid:29163407 PMCid:PMC5671610

72. Roychoudhury P, Swan DA, Duke E, Corey L, Zhu J, Davé V, Spuhler LR, Lund JM, Prlic M, Schiffer JT. Tissue-resident T cell-derived cytokines eliminate herpes simplex virus-2infected cells. The Journal of clinical investigation. 2020 Apr 27;130(6). https://doi.org/10.1172/JCl132583 PMid: 32125285 PMCid:PMC7260013

73. Cunningham AL, Diefenbach RJ, Miranda-Saksena M, Bosnjak L, Kim M, Jones C, Douglas MW. The cycle of human herpes simplex virus infection: virus transport and immune control. The Journal of infectious diseases. 2006 Sep 1;194(Supplement_1):S11-8. https://doi.org/10.1086/505 359 PMid:16921466

74. Stock C, Guillen-Grima F, de Mendoza JH, Marin-Fernandez $B$, Aguinaga-Ontoso I, Krämer A. Risk factors of herpes simplex type 1 (HSV-1) infection and lifestyle factors associated with HSV-1 manifestations. European journal of epidemiology. 2001 Sep 1;17(9):885-90. https://doi.org/ 10.1023/A:1015652713971 PMid:12081109

75. Kropp RY, Wong T, Cormier L, Ringrose A, Burton S, Embree JE, Steben M. Neonatal herpes simplex virus infections in Canada: results of a 3-year national prospective study. Pediatrics. 2006 Jun 1;117(6):1955-62. https://doi.org/ 10.1542/peds.2005-1778 PMid:16740836

76. Stock C, Wille L, Krämer A. Gender-specific health behaviors of German university students predict the interest in campus health promotion. Health promotion international. 2001 Jun 1;16(2):145-54. https://doi.org/ 10.1093/heapro/16.2.145 PMid:11356753

77. Malkin JE, Morand P, Malvy D, Ly TD, Chanzy B, De Labareyre C, El Hasnaoui A, Hercberg S. Seroprevalence of HSV-1 and HSV-2 infection in the general French population. Sexually transmitted infections. 2002 Jun 1;78(3):201-3. https://doi.org/10.1136/sti.78.3.201 PMid: 12238654 PMCid:PMC1744464

78. Burrel S, Boutolleau D, Ryu D, Agut H, Merkel K, Leendertz $\mathrm{FH}$, Calvignac-Spencer S. Ancient recombination events between human herpes simplex viruses. Molecular biology and evolution. 2017 Jul 1;34(7):1713-21. https://doi.org/ 10.1093/molbev/msx113 PMid:28369565 PMCid: PMC5455963

79. Hercberg S, Galan P, Preziosi P, Bertrais S, Mennen L, Malvy D, Roussel AM, Favier A, Briançon S. The SU. VI. MAX Study: a randomized, placebo-controlled trial of the health effects of antioxidant vitamins and minerals. Archives of internal medicine. 2004 Nov 22;164(21):2335-42. https://doi.org/ 10.1001/archinte.164.21.2335 PMid:15557412

80. Hercberg S. The SU. VI. MAX study, a randomized, placebocontrolled trial on the effects of antioxidant vitamins and minerals on health. InAnnales pharmaceutiques francaises 2006 Nov;64(6):397-401. https://doi.org/10.1016/S00034509(06)75335-4
81. Hercberg S, Galan P, Preziosi P, Roussel AM, Arnaud J, Richard MJ, Malvy D, Paul-Dauphin A, Briancon S, Favier A. Background and rationale behind the SU. VI. MAX Study, a prevention trial using nutritional doses of a combination of antioxidant vitamins and minerals to reduce cardiovascular diseases and cancers. Supplementation en VItamines et Minéraux AntioXydants Study. International journal for vitamin and nutrition research. Internationale Zeitschrift fur Vitamin-und Ernahrungsforschung. Journal international de vitaminologie et de nutrition. 1998;68(1):320.

82. Roberts CM, Pfister JR, Spear SJ. Increasing proportion of herpes simplex virus type 1 as a cause of genital herpes infection in college students. Sexually transmitted diseases. 2003 Oct 1;30(10):797-800. https://doi.org/ 10.1097/01.OLQ.0000092387.58746.C7 PMid:14520181

83. American College Health Association. National college health assessment: Reference group executive summary. Hanover: American College Health Association. 2010.

84. Bernstein DI, Bellamy AR, Hook III EW, Levin MJ, Wald A, Ewell MG, Wolff PA, Deal CD, Heineman TC, Dubin G, Belshe RB. Epidemiology, clinical presentation, and antibody response to primary infection with herpes simplex virus type 1 and type 2 in young women. Clinical Infectious Diseases. 2013 Feb 1;56(3):344-51. https://doi.org/ 10.1093/cid/cis891 PMid:23087395 PMCid:PMC3540038

85. McQuillan GM, Kruszon-Moran D, Flagg EW, Paulose-Ram R. Prevalence of herpes simplex virus type 1 and type 2 in persons aged 14-49: United States, 2015-2016. US Department of Health and Human Services, Centers for Disease Control and Prevention, National Center for Health Statistics; 2018 Feb.

86. Bradley H, Markowitz LE, Gibson T, McQuillan GM. Seroprevalence of herpes simplex virus types 1 and 2United States, 1999-2010. The Journal of infectious diseases. 2014 Feb 1;209(3):325-33. https://doi.org/ 10.1093/infdis/jit458 PMid:24136792

87. Brugha R, Keersmaekers K, Renton A, Meheus A. Genital herpes infection: a review. International journal of epidemiology. 1997 Aug 1;26(4):698-709. https://doi.org/ 10.1093/ije/26.4.698 PMid:9279600

88. Qutub M, Akhter J. Epidemiology of genital herpes (HSV-2) among brothel based female sex workers in Bangladesh. European journal of epidemiology. 2003 Sep 1;18(9):903-5. https://doi.org/10.1023/A:1025607913408 PMid:14561051

89. Cowan FM, French RS, Mayaud P, Gopal R, Robinson NJ, De Oliveira SA, Faillace T, Uusküla A, Nygård-Kibur $M$, Ramalingam S, Sridharan G. Seroepidemiological study of herpes simplex virus types 1 and 2 in Brazil, Estonia, India, Morocco, and Sri Lanka. Sex Transm Infect. 2003 Aug 1;79(4):286-90. https://doi.org/10.1136/sti.79.4.286 PMid:12902576 PMCid:PMC1744730

90. Hashido M, Lee FK, Nahmias AJ, Tsugami H, Isomura S, Nagata Y, Sonoda S, Kawana T. An epidemiologic study of herpes simplex virus type 1 and 2 infection in Japan based on type-specific serological assays. Epidemiology \& Infection. 1998 Mar;120(2):179-86. https://doi.org/10.1017 /S095026889700856X PMid:9593488 PMCid:PMC2809388

91. Doi Y, Ninomiya T, Hata J, Yonemoto K, Tanizaki Y, Arima H, Liu Y, Rahman M, lida M, Kiyohara Y. Seroprevalence of herpes simplex virus 1 and 2 in a population-based cohort in Japan. Journal of epidemiology. 2009 Mar 5:0903030072. https://doi.org/10.2188/jea.JE20080061 PMid:19265271 PMCid:PMC3924115 
92. Lin H, He N, Su M, Feng J, Chen L, Gao M. Herpes simplex virus infections among rural residents in eastern China. BMC infectious diseases. 2011 Dec;11(1):69. https://doi.org/10.1186/1471-2334-11-69 PMid:21414231 PMCid:PMC3068093

93. Liang YY, Zhai HY, Li ZJ, Jin X, Chen Y, Chen SP. Prevalence of Ureaplasma urealyticum, Chlamydia trachomatis, Neisseria gonorrhoeae and herpes simplex virus in Beijing, China. Epidemiology \& Infection. 2019;147. https://doi.org/10.1017/S0950268818003163 PMid:30501682 PMCid:PMC6518584

94. Chaabane S, Harfouche M, Chemaitelly H, Schwarzer G, Abu-Raddad LJ. Herpes simplex virus type 1 epidemiology in the Middle East and North Africa: systematic review, meta-analyses, and meta-regressions. Scientific reports. 2019 Feb 4;9(1):1-1. https://doi.org/10.1038/s41598-01837833-8 PMid:30718696 PMCid:PMC6362060

95. Ibrahim Al, Obeid MT, Jouma MJ, Roemer K, MuellerLantzsch N, Gärtner BC. Prevalence of herpes simplex virus (types 1 and 2), varicella-zoster virus, cytomegalovirus, and human herpesvirus 6 and 7 DNA in cerebrospinal fluid of Middle Eastern patients with encephalitis. Journal of clinical microbiology. 2005 Aug 1;43(8):4172-4. https://doi.org/10.1128/JCM.43.8.4172-4174.2005 PMid:16081968 PMCid:PMC1233955

96. Nabi SN, Wasey AF, Haider KM, Khan AA, Hoque MM. Seroprevalence of TORCH antibody in pregnant women. Journal Of Armed Forces Medical College, Bangladesh. 2012;8(1):35-9. https://doi.org/10.3329/jafmc.v8i1.13537

97. Nasrallah GK, Dargham SR, Mohammed LI, Abu-Raddad LJ. Estimating seroprevalence of herpes simplex virus type 1 among different Middle East and North African male populations residing in Qatar. Journal of medical virology. 2018 Jan;90(1):184-90. https://doi.org/10.1002/jmv.24916 PMid:28817197 PMCid:PMC5724503

98. Patnaik P, Herrero R, Morrow RA, MuNOz N, Bosch FX, Bayo S, El Gueddari B, Caceres E, Chichareon SB, Castellsague X, Meijer CJ. Type-specific seroprevalence of herpes simplex virus type 2 and associated risk factors in middle-aged women from 6 countries: the IARC multicentric study. Sexually transmitted diseases. 2007 Dec 1;34(12):1019-24 https://doi.org/10.1097/OLQ.0b013e31811f4118 PMid: 18080353

99. Cowan FM, French RS, Mayaud P, Gopal R, Robinson NJ, De Oliveira SA, Faillace T, Uusküla A, Nygård-Kibur M, Ramalingam S, Sridharan G. Seroepidemiological study of herpes simplex virus types 1 and 2 in Brazil, Estonia, India, Morocco, and Sri Lanka. Sex Transm Infect. 2003 Aug 1;79(4):286-90. https://doi.org/10.1136/sti.79.4.286 PMid:12902576 PMCid:PMC1744730

100. Pereira VS, Moizeis RN, Fernandes TA, Araújo JM, Meissner RV, Fernandes JV. Herpes simplex virus type 1 is the main cause of genital herpes in women of Natal, Brazil. European Journal of Obstetrics \& Gynecology and Reproductive Biology. 2012 Apr 1;161(2):190-3. https://doi.org/10.1016/j.ejogrb.2011.12.006 PMid:22424592

101. Lupi O. Prevalence and risk factors for herpes simplex infection among patients at high risk for HIV infection in Brazil. International journal of dermatology. 2011 Jun;50(6):709-13. https://doi.org/10.1111/j.1365-4632. 2010.04863.x PMid:21595666
102. Cunningham AL, Taylor R, Taylor J, Marks C, Shaw J, Mindel A. Prevalence of infection with herpes simplex virus types 1 and 2 in Australia: a nationwide population based survey. Sexually transmitted infections. $2006 \mathrm{Apr}$ 1;82(2):164-8. https://doi.org/10.1136/sti.2005.016899 PMid:16581748 PMCid:PMC2564694

103. Tran T, Druce JD, Catton MC, Kelly H, Birch CJ. Changing epidemiology of genital herpes simplex virus infection in Melbourne, Australia, between 1980 and 2003. Sexually transmitted infections. 2004 Aug 1;80(4):277-9. https://doi.org/10.1136/sti.2004.009753 PMid:15295125 PMCid:PMC1744857

104. Durukan D, Fairley CK, Bradshaw CS, Read TR, Druce J, Catton M, Caly L, Chow EP. Increasing proportion of herpes simplex virus type 1 among women and men diagnosed with first-episode anogenital herpes: a retrospective observational study over 14 years in Melbourne, Australia. Sexually transmitted infections. 2019 Jun 1;95(4):307-13. https://doi.org/10.1136/sextrans-2018-053830 PMid:30554143

105. James C, Harfouche M, Welton NJ, Turner KM, Abu-Raddad LJ, Gottlieb SL, Looker KJ. Herpes simplex virus: global infection prevalence and incidence estimates, 2016. Bulletin of the World Health Organization. 2020 May 1;98(5):315. https://doi.org/10.2471/BLT.19.237149 PMid: 32514197 PMCid:PMC7265941

106. Lee FK, Pereira L, Griffin C, Reid E, Nahmias A. A novel glycoprotein for detection of herpes simplex virus type 1specific antibodies. Journal of virological methods. 1986 Sep 1;14(2):111-8. https://doi.org/10.1016/0166-0934(86) 90041-8

107. Honess RW, Powell KL, Robinson DJ, Sim C, Watson DH. Type specific and type common antigens in cells infected with herpes simplex virus type 1 and on the surfaces of naked and enveloped particles of the virus. Journal of General Virology. 1974 Feb 1;22(2):159-69. https://doi.org/ 10.1099/0022-1317-22-2-159 PMid:4132223

108. Mark HD, Nanda JP, Roberts J, Rompalo A, Melendez JH, Zenilman J. Performance of focus ELISA tests for HSV-1 and HSV-2 antibodies among university students with no history of genital herpes. Sexually transmitted diseases. 2007 Sep;34(9):681. https://doi.org/10.1097/01.olq. 0000258307.18831.f0 PMid:17457239 PMCid:PMC2648390

109. Matić-Petrović S, Zelić K, Milašin J, Popović B, Pucar A, Zelić $O$. Detection of herpes simplex virus type 1 in gingival crevicular fluid of gingival sulcus/periodontal pocket using polymerase chain reaction. Srpski arhiv za celokupno lekarstvo. 2014;142(5-6):296-300. https://doi.org/10.2298/ SARH1406296M

110. Navidad J, Pfotenhauer B, Leigh N, Maas E, Gradus S, Bhattacharyya S. Clinical evaluation and cost analysis of a Trioplex real-time PCR assay for the detection and differentiation of herpes simplex virus 1 and 2 in cutaneous and mucocutaneous lesions. Journal of medical microbiology. 2019 May 1;68(5):748-54. https://doi.org/10.1099/jmm.0.000971 PMid:30938666

111. De Clercq E. Antiviral drugs in current clinical use. Journal of clinical virology. 2004 Jun 1;30(2):115-33. https://doi.org/10.1016/j.jcv.2004.02.009 PMid:15125867 
112. McKeough MB, Spruance SL. Comparison of new topical treatments for herpes labialis: efficacy of penciclovir cream, acyclovir cream, and n-docosanol cream against experimental cutaneous herpes simplex virus type 1 infection. Archives of dermatology. 2001 Sep 1;137(9):1153-8. https://doi.org/10.1001/archderm.137.9. 1153 PMid: 11559210

113. Mohseni AH, Taghinezhad-S S, Keyvani H, Ghobadi N. Comparison of acyclovir and multistrain Lactobacillus brevis in women with recurrent genital herpes infections: a double-blind, randomized, controlled study. Probiotics and antimicrobial proteins. 2018 Dec;10(4):740-7. https://doi.org/10.1007/s12602-017-9320-8 PMid:28852985

114. Birkmann A, Zimmermann H. HSV antivirals-current and future treatment options. Current opinion in virology. 2016 Jun 1;18:9-13. https://doi.org/10.1016/j.coviro.2016.01. 013 PMid:26897058

115. Whitley R, Baines J. Clinical management of herpes simplex virus infections: past, present, and future. F1000Research. 2018;7. https://doi.org/10.12688/f1000 research.16157.1 PMid:30443341 PMCid:PMC6213787

116. van Velzen M, Missotten T, van Loenen FB, Meesters RJ, Luider TM, Baarsma GS, Osterhaus AD, Verjans GM. Acyclovir-resistant herpes simplex virus type 1 in intraocular fluid samples of herpetic uveitis patients. Journal of Clinical Virology. 2013 Jul 1;57(3):215-21. https://doi.org/ 10.1016/j.jcv.2013.03.014 PMid:23582986

117. Frobert E, Burrel S, Ducastelle-Lepretre S, Billaud G, Ader F, Casalegno JS, Nave V, Boutolleau D, Michallet M, Lina B, Morfin F. Resistance of herpes simplex viruses to acyclovir: an update from a ten-year survey in France. Antiviral research. 2014 Nov 1;111:36-41 https://doi.org/10.1016/ j.antiviral.2014.08.013 PMid:25218782

118. Boyd MR, Bacon TH, Sutton DA, Cole MA. Antiherpesvirus activity of 9-(4-hydroxy-3-hydroxy-methylbut-1-yl) guanine (BRL 39123) in cell culture. Antimicrobial agents and chemotherapy. 1987 Aug 1;31(8):1238-42. https://doi.org/10.1128/AAC.31.8.1238 PMid:3631945 PMCid:PMC174911

119. Sekita Y, Murakami K, Yumoto H, Hirao K, Amoh T, Fujiwara $\mathrm{N}$, Hirota K, Fujii H, Matsuo T, Miyake Y, Kashiwada Y. Antibiofilm and anti-inflammatory activities of houttuynia cordata decoction for oral care. Evidence-Based Complementary and Alternative Medicine. 2017;2017. https://doi.org/10.1155/2017/2850947ＰMid:29234378 PMCid:PMC5662838

120. Chiang LC, Chang JS, Chen CC, Ng LT, Lin CC. Anti-Herpes simplex virus activity of Bidens pilosa and Houttuynia cordata. The American journal of Chinese medicine. 2003;31(03):355-62. https://doi.org/10.1142/S0192415X03 001090 PMid: 12943167

121. Li W, Wang XH, Luo Z, Liu LF, Yan C, Yan CY, Chen GD, Gao $H$, Duan WJ, Kurihara H, Li YF. Traditional Chinese medicine as a potential source for HSV-1 therapy by acting on virus or the susceptibility of host. International journal of molecular sciences. 2018 Oct;19(10):3266. https://doi.org/10.3390/ijms19103266 PMid:30347851 PMCid:PMC6213986

122. Clem AS. Fundamentals of vaccine immunology. Journal of global infectious diseases. 2011 Jan;3(1):73. https://doi.org/10.4103/0974-777X.77299 PMid:21572612 PMCid:PMC3068582
123. Awasthi S, Lubinski JM, Eisenberg RJ, Cohen GH, Friedman HM. An HSV-1 gD mutant virus as an entry-impaired live virus vaccine. Vaccine. 2008 Feb 26;26(9):1195-203. https://doi.org/10.1016/j.vaccine.2007.12.032 PMid:18243431 PMCid:PMC2680698

124. Leroux-Roels $G$, Clément $F$, Vandepapelière $P$, Fourneau $M$, Heineman T, Dubin G. Immunogenicity and safety of different formulations of an adjuvanted glycoprotein $D$ genital herpes vaccine in healthy adults: a double-blind randomized trial. Human vaccines \& immunotherapeutics. 2013 Jun 12;9(6):1254-62. https://doi.org/10.4161/ hv.24043 PMid:23434737 PMCid:PMC3901814

125. Wald A, Bernstein D, Fife K, Lee P, Tyring S, Van Wagoner N. Novel therapeuticvaccine for genital herpes reduces genital HSV-2 shedding. In: 53rd InterscienceConference on Antimicrobial Agents and Chemotherapy. 2013.

126. Long D, Skoberne M, Gierahn TM, Larson S, Price JA, Clemens $V$, et al.Identification of novel virus-specific antigens by $\mathrm{CD} 4+$ and $\mathrm{CD} 8+\mathrm{T}$ cellsfrom asymptomatic HSV-2 seropositive and seronegative donors. Virology2014;464-465:296-311. https://doi.org/10.1016/ j.virol.2014.07.018 PMid:25108380

127. Skoberne M, Cardin R, Lee A, Kazimirova A, Zielinski V, Garvie D, et al. Anadjuvanted herpes simplex virus 2 subunit vaccine elicits a $T$ cell responsein mice and is an effective therapeutic vaccine in guinea pigs. J Virol2013;87(7):3930-42. https://doi.org/10.1128/JVI.027 45-12 PMid:23365421 PMCid:PMC3624190

128. Wald A, Koelle DM, Fife K, Warren T, Leclair K, Chicz RM, et al. Safety andimmunogenicity of long HSV-2 peptides complexed with rhHsc70 in HSV-2seropositive persons. Vaccine 2011;29(47):8520-9. https://doi.org/10.1016/ j.vaccine.2011.09.046 PMid:21945262

129. Dutton JL, Li B, Woo W-P, Marshak JO, Xu Y, Huang M-l, et al. A novel DNAvaccine technology conveying protection against a lethal herpes simplex viralchallenge in mice. PLOS ONE 2013;8(10):e76407. https://doi.org/10.1371/ journal.pone.0076407 PMid:24098493 PMCid:PMC3789751

130. Veselenak RL, Shlapobersky M, Pyles RB, Wei Q, Sullivan SM, Bourne N. AVaxfectin ${ }^{\circledR}$-adjuvanted HSV-2 plasmid DNA vaccine is effective for prophy-lactic and therapeutic use in the guinea pig model of genital herpes. Vaccine2012;30(49):7046-51. https://doi.org/10.1016/ j.vaccine.2012.09.057 PMid:23041125 PMCid:PMC3807597

131. Bernard M-C, Barban V, Pradezynski F, de Montfort A, Ryall $\mathrm{R}$, CailletC, et al. Immunogenicity protective efficacy, and non-replicative status ofthe HSV-2 vaccine candidate HSV529 in mice and Guinea pigs. PLOS ONE2015;10(4):e0121518. https://doi.org/10.1371/journal. pone.0121518 PMid:25837802 PMCid:PMC4383384

132. Awasthi S, Huang J, Shaw C, Friedman HM. Blocking herpes simplex virus2 glycoprotein $\mathrm{E}$ immune evasion as an approach to enhance Efficacy ofa trivalent subunit antigen vaccine for genital herpes. J Virol 2014;88(15):8421-32. https://doi.org/10.1128/JVI.0113014 PMid:24829358 PMCid:PMC4135967

133. Halford WP, Puschel R, Gershburg E, Wilber A, Gershburg S, Rakowski B.A live-attenuated HSV-2 ICPO-virus elicits 10 to 100 times greater protec-tion against genital herpes than a glycoprotein D subunit vaccine. PLoS ONE2011;6(3):e17748. https://doi.org/10.1371/journal.po ne.0017748 PMid:21412438 PMCid:PMC3055896 
134. Luo C, Goshima F, Kamakura M, Mutoh Y, Iwata S, Kimura $\mathrm{H}$, et al. Immunizationwith a highly attenuated replicationcompetent herpes simplex virus type 1mutant HF10, protects mice from genital disease caused by herpes simplexvirus type 2. Front Microbiol 2012;3:158. https://doi.org/10.3389/fmicb.2012.00158 PMid:22557998 PMCid:PMC3339446

135. Petro C, González PA, Cheshenko N, Jandl T, Khajoueinejad N, Bénard A, et al.Herpes simplex type 2 virus deleted in glycoprotein $D$ protects against vaginal,skin and neural disease. elife 2015;4:e06054. https://doi.org/10.7554/eLife.06054 PMid:25756612 PMCid:PMC4352706

136. Prichard MN, Kaiwar R, Jackman WT, Quenelle DC, Collins DJ, Kern ER, et al.Evaluation of AD472: a live attenuated recombinant herpes simplex virus type2 vaccine in guinea pigs. Vaccine 2005;23(46-47):5424-31. https://doi.org/ 10.1016/j.vaccine.2005.02.028 PMid:15950327 PMCid: PMC2718572

137. Zhang P, Xie L, Balliet JW, Casimiro D, Yao F. Herpes simplex virus 2 (HSV-2) gly-coprotein dexpressing nonreplicating dominant-negative HSV-2 virus vaccineis superior to a gD2 subunit vaccine against HSV-2 genital infection in Guineapigs. PLOS ONE 2014;9(6):1-9. https://doi.org/10.1371/journal.pone.0101373 PMid:24979708 PMCid:PMC4076306

138. Shin $H$, Iwasaki A. A vaccine strategy that protects against genital herpes byestablishing local memory T cells. Nature 2012;491(7424):463-7. https://doi.org/10.1038/nature 11522 PMid:23075848 PMCid:PMC3499630

139. Morello CS, Kraynyak KA, Levinson MS, Chen Z, Lee K-F, Spector DH. InactivatedHSV-2 in MPL/alum adjuvant provides nearly complete protection against gen-ital infection and shedding following long term challenge and rechallenge. Vaccine 2012;30(46):6541-50. https://doi.org/ 10.1016/j.vaccine.2012.08.049 PMid:22947141 PMCid: PMC3754855

140. Chiuppesi F, Vannucci L, De Luca A, Lai M, Matteoli B, Freer $G$, et al. Alentiviral vector-based, herpes simplex virus 1 (HSV-1) glycoprotein B vaccineaffords cross-protection against HSV-1 and HSV-2 genital infections. J Virol2012;86(12):6563-74. https://doi.org/10.1128/JVI.00 302-12 PMid:22491465 PMCid:PMC3393530

141. Cortesi R, Ravani L, Rinaldi F, Marconi P, Drechsler M, Manservigi $M$, et al.Intranasal immunization in mice with non-ionic surfactants vesicles contain-ing HSV immunogens: a preliminary study as possible vaccine against genitalherpes. Int J Pharm 2013;440(2):229-37. https://doi.org/10.1016/j.ijpharm.2012.06.042

PMid:22743007

142. Royer DJ, Hendrix JF, Larabee CM, Reagan AM, Sjoelund VH, Robertson DM, Carr DJ. Vaccine-induced antibodies target sequestered viral antigens to prevent ocular HSV-1 pathogenesis, preserve vision, and preempt productive neuronal infection. Mucosal immunology. 2019 May;12(3):827-39. https://doi.org/10.1038/s41385-0190131-y PMid:30670763 PMCid:PMC6462227

143. Belshe RB, Leone PA, Bernstein DI, Wald A, Levin MJ, Stapleton JT, Gorfinkel I, Morrow RL, Ewell MG, StokesRiner A, Dubin G. Efficacy results of a trial of a herpes simplex vaccine. New England Journal of Medicine. 2012 Jan 5;366(1):34-43. https://doi.org/10.1056/NEJMoa 1103151 PMid:22216840 PMCid:PMC3287348
144. McLean CS, Erturk M, Jennings R, Ni Challanain D, Minson AC, Duncan I, Boursnell ME, Inglis SC. Protective vaccination against primary and recurrent disease caused by herpes simplex virus (HSV) type 2 using a genetically disabled HSV-1. Journal of Infectious Diseases. 1994 Nov 1;170(5):1100-9. https://doi.org/10.1093/infdis/170.5.1100 PMid:7963701

145. Lu Z, Brans R, Akhrameyeva NV, Murakami N, Xu X, Yao F. High-level expression of glycoprotein $D$ by a dominantnegative HSV-1 virus augments its efficacy as a vaccine against HSV-1 infection. Journal of investigative dermatology. 2009 May 1;129(5):1174-84. https://doi.org/ 10.1038/jid.2008.349 PMid:19005489 PMCid:PMC2669847

146. De Chiara G, Piacentini R, Fabiani M, Mastrodonato A, Marcocci ME, Limongi D, Napoletani G, Protto V, Coluccio $\mathrm{P}$, Celestino I, Puma DD. Recurrent herpes simplex virus-1 infection induces hallmarks of neurodegeneration and cognitive deficits in mice. PLoS pathogens. 2019 Mar;15(3). https://doi.org/10.1371/journal.ppat.1007617 PMid:30870531 PMCid:PMC6417650

147. Herpes simplex virus. Who.int. 2020. Available at: https://www.who.int/news-room/fact-sheets/detail/ herpes-simplex-virus (Accessed: 11 September 2020).

148. De Chiara G, Piacentini R, Fabiani M, Mastrodonato A, Marcocci ME, Limongi D, Napoletani G, Protto V, Coluccio $\mathrm{P}$, Celestino I, Puma DD. Recurrent herpes simplex virus-1 infection induces hallmarks of neurodegeneration and cognitive deficits in mice. PLoS pathogens. 2019 Mar;15(3). https://doi.org/10.1371/journal.ppat.1007617 PMid:30870531 PMCid:PMC6417650

149. Kulshreshtha G, Burlot AS, Marty C, Critchley A, Hafting J, Bedoux G, Bourgougnon N, Prithiviraj B. Enzyme-assisted extraction of bioactive material from Chondrus crispus and Codium fragile and its effect on herpes simplex virus (HSV-1). Marine drugs. 2015 Jan;13(1):558-80. https://doi.org/10.3390/md13010558 PMid:25603348 PMCid:PMC4306952

150. Guo YJ, Luo T, Wu F, Mei YW, Peng J, Liu H, Li HR, Zhang SL, Dong JH, Fang Y, Zhao L. Involvement of TLR2 and TLR9 in the anti-inflammatory effects of chlorogenic acid in HSV-1infected microglia. Life sciences. 2015 Apr 15;127:12-8. https://doi.org/10.1016/j.lfs.2015.01.036 PMid:25744394

151. Coelho GR, Mendonça RZ, Vilar KD, Figueiredo CA, Badari JC, Taniwaki N, Namiyama G, Oliveira MI, Curti SP, Evelyn Silva P, Negri G. Antiviral action of hydromethanolic extract of geopropolis from Scaptotrigona postica against antiherpes simplex virus (HSV-1). Evidence-Based Complementary and Alternative Medicine. 2015;2015. https://doi.org/10.1155/2015/296086 PMid:25861357 PMCid:PMC4377393

152. Musarra-Pizzo M, Pennisi R, Ben-Amor I, Smeriglio A, Mandalari G, Sciortino MT. In Vitro Anti-HSV-1 Activity of Polyphenol-Rich Extracts and Pure Polyphenol Compounds Derived from Pistachios Kernels (Pistacia vera L.). Plants. 2020 Feb;9(2):267. https://doi.org/10.3390/ plants9020267 PMid:32085514 PMCid:PMC7076519

153. Rittà M, Marengo A, Civra A, Lembo D, Cagliero C, Kant K, Lal UR, Rubiolo P, Ghosh M, Donalisio M. Antiviral Activity of a Arisaema Tortuosum Leaf Extract and Some of its Constituents against Herpes Simplex Virus Type 2. Planta Medica. 2020 Mar;86(04):267-75. https://doi.org/10.1055/ a-1087-8303 PMid:31968380 
154. Wang Z, Jia J, Wang L, Li F, Wang Y, Jiang Y, Song X, Qin S, Zheng K, Ye J, Ren Z. Anti-HSV-1 activity of Aspergillipeptide $\mathrm{D}$, a cyclic pentapepetide isolated from fungus Aspergillus sp. SCSIO 41501. Virology journal. 2020 Dec;17(1):1-9. https://doi.org/10.1186/s12985-020-013220 PMid:32238179 PMCid:PMC7110650

155. Michaelis M, Kleinschmidt MC, Rabenau HF, Wass MN, Cinatl Jr J. Omeprazole increases the efficacy of acyclovir against herpes simplex virus type 1 and 2. Frontiers in Microbiology. 2019;10:2790. https://doi.org/10.3389/ fmicb.2019.02790 PMid:31849920 PMCid:PMC6901432

156. Azzam RA, Osman RR, Elgemeie GH. Efficient Synthesis and Docking Studies of Novel Benzothiazole-Based Pyrimidinesulfonamide Scaffolds as New Antiviral Agents and Hsp90a Inhibitors. ACS Omega. 2020 Jan 9. https://doi.org/10.1021/acsomega.9b03706 PMid:32010839 PMCid:PMC6990646
157. Rutkowski AJ, Erhard F, L'Hernault A, Bonfert T, Schilhabel M, Crump C, Rosenstiel P, Efstathiou S, Zimmer R, Friedel CC, Dölken L. Widespread disruption of host transcription termination in HSV-1 infection. Nature communications. 2015 May 20;6:7126. https://doi.org/10.1038/ncomms8126 PMid:25989971 PMCid:PMC4441252

158. Yu X, Li Y, Chen Q, Su C, Zhang Z, Yang C, Hu Z, Hou J, Zhou J, Gong L, Jiang X. Herpes simplex virus 1 (HSV-1) and HSV2 mediate species-specific modulations of programmed necrosis through the viral ribonucleotide reductase large subunit R1. Journal of virology. 2016 Jan 15;90(2):1088-95. https://doi.org/10.1128/JVI.02446-15

PMid:26559832 